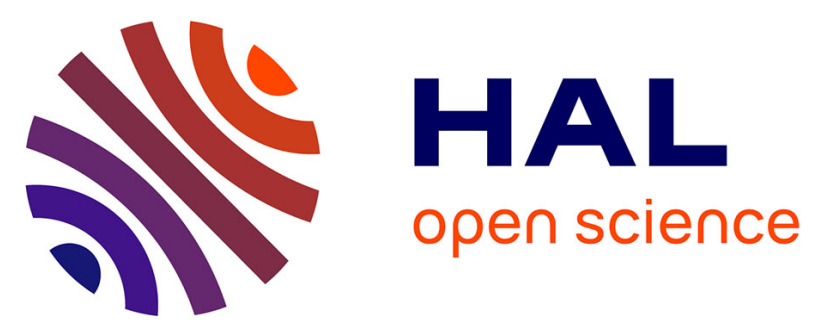

\title{
Element distribution in the root zone of ultramafic-hosted black smoker-like systems: Constraints from an Alpine analog
}

Rémi Coltat, Philippe Boulvais, T. Riegler, E. Pelleter, Yannick Branquet

\section{- To cite this version:}

Rémi Coltat, Philippe Boulvais, T. Riegler, E. Pelleter, Yannick Branquet. Element distribution in the root zone of ultramafic-hosted black smoker-like systems: Constraints from an Alpine analog. Chemical Geology, 2021, 559, pp.119916. 10.1016/j.chemgeo.2020.119916 . insu-02962200

\section{HAL Id: insu-02962200 \\ https://hal-insu.archives-ouvertes.fr/insu-02962200}

Submitted on 9 Oct 2020

HAL is a multi-disciplinary open access archive for the deposit and dissemination of scientific research documents, whether they are published or not. The documents may come from teaching and research institutions in France or abroad, or from public or private research centers.
L'archive ouverte pluridisciplinaire $\mathbf{H A L}$, est destinée au dépôt et à la diffusion de documents scientifiques de niveau recherche, publiés ou non, émanant des établissements d'enseignement et de recherche français ou étrangers, des laboratoires publics ou privés. 


\section{Journal Pre-proof}

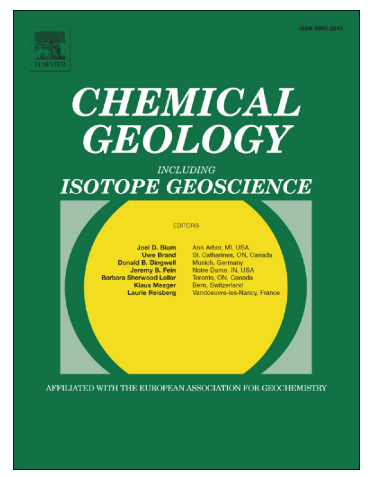

Element distribution in the root zone of ultramafic-hosted black smoker-like systems: Constraints from an Alpine analog

R. Coltat, P. Boulvais, T. Riegler, E. Pelleter, Y. Branquet

PII: $\quad$ S0009-2541(20)30455-1

DOI: $\quad$ https://doi.org/10.1016/j.chemgeo.2020.119916

Reference: $\quad$ CHEMGE 119916

To appear in: $\quad$ Chemical Geology

Received date: $\quad 15$ April 2020

Revised date: $\quad 15$ September 2020

Accepted date: $\quad 5$ October 2020

Please cite this article as: R. Coltat, P. Boulvais, T. Riegler, et al., Element distribution in the root zone of ultramafic-hosted black smoker-like systems: Constraints from an Alpine analog, Chemical Geology (2020), https://doi.org/10.1016/j.chemgeo.2020.119916

This is a PDF file of an article that has undergone enhancements after acceptance, such as the addition of a cover page and metadata, and formatting for readability, but it is not yet the definitive version of record. This version will undergo additional copyediting, typesetting and review before it is published in its final form, but we are providing this version to give early visibility of the article. Please note that, during the production process, errors may be discovered which could affect the content, and all legal disclaimers that apply to the journal pertain.

(C) 2020 Published by Elsevier. 


\title{
Element distribution in the root zone of ultramafic-hosted black smoker-like systems: constraints from an Alpine analog
}

R. Coltat ${ }^{1}$, P. Boulvais ${ }^{1}$, T. Riegler ${ }^{2}$, E. Pelleter ${ }^{3}$ and Y. Branquet ${ }^{1,4}$

${ }^{1}$ Géosciences Rennes, CNRS UMR 6118, Université Rennes, F-35000 Rennes, France

${ }^{2}$ Department of Geology, Trinity College Dublin, Dublin, Ireland

${ }^{3}$ IFREMER Centre de Brest, DRO/GM, Plouzané, France

${ }^{4}$ ISTO, UMR7327, Université d'Orléans, CNRS, BR $r_{\text {sIvi, }} 45071$ Orléans, France Corresponding author: remi.coltat@univ-rennes1.fr

Keywords: Ultramafic-hosted black smckers, root zones, element distribution, Mid-oceanic Ridges, extension. Il r etachment, Alps

\begin{abstract}
Fluid-rock interactions at Mid-Oceanir Ridges lead to metal deposition in the so-called seafloor massive sulfides at ultramafi -hostea systems. Due to restricted access to the seafloor and scarcity of 3D exposures, these $y^{\text {ten }}$ is are poorly understood at-depth. A way to access the vertical dimension is to for $u_{n} u_{n}$ fossil analogs preserved on-land such as the one preserved in serpentinites fro 1 tho Platta nappe (SE Switzerland). For this example, we document the element distribut $\cdot n$ in the mineralized rocks at three distinct levels in the rock column using both wh sle rock chemical analyses and LA-ICPMS analysis of sulfide (chalcopyrite and pyrrho : te) and magnetite. We bring, for the first time, chemical signatures of the mineralization in the root zone of ultramafic-hosted black smokers. At any given depth, the $\mathrm{Co} / \mathrm{Ni}$ ratio is maximum in the most mineralized samples indicating that this ratio is linked to the intensity of hydrothermal alteration. Additionally, the $\mathrm{Co} / \mathrm{Ni}$ ratio decreases in mineralized rocks towards the paleosurface, whereas the Se content increases. An episode of carbonation recorded in the highest structural level of the system was responsible for a slight remobilization of the former $\mathrm{Cu}$ stock. We propose a model in which the uprising mineralizing fluid mixed with seawater within the host serpentinites, before venting at the paleoseafloor.
\end{abstract}

\section{Introduction}


Mineralized systems have been recognized and studied in many tectonic settings. At spreading centers, the evidence of active hydrothermalism leading to metal deposition is recorded through the formation of the so-called high-temperature $\left(\mathrm{HT}\right.$; i.e. $\left.>300^{\circ} \mathrm{C}\right)$ black and "low-temperature" (LT; i.e. 250-300 ${ }^{\circ}$ C) white smokers (Hannington et al., 1995; Tivey, 2007). Over the last three decades, the number of mineralized systems reported along midoceanic ridges has considerably increased reinforcing the statement that hydrothermalism is a fundamental process at all spreading-rate mid-oceanic ridges (Beaulieu et al., 2013).

HT black smokers have been firstly recognized along the fast-spreading East Pacific Rise (EPR) in early 80's (RISE Project Group, 1980). The more racent exploration of the slowspreading Mid-Atlantic Ridge and ultraslow-spreading South $\mathbf{V}_{\mathrm{es}}+$ Indian Ridge allowed to identify HT black smoker venting at lower spreading-rate ridy= (Rona, 1985; Fouquet et al., 2010; Tao et al., 2012). In these settings, black sm(kc * can be either associated with sedimentary rocks (Zierenberg et al., 1993), maf ¿ i cks (Hannington et al., 1995) or ultramafic rocks where mantle exhumation is accr $m_{1}$. ndated by detachment faulting (i.e. along the oceanic core complexes at slow-spreac ir.g idges, Fouquet et al., 2010).

Because of the nature of the host rock, nin ralization at mafic-hosted and ultramafic-hosted hydrothermal systems are slightly different. They consist of Fe-Cu-Zn-rich deposits in mafic settings and $\mathrm{Cu}-\mathrm{Co}-\mathrm{Zn}-(\mathrm{Ni})-(\mathrm{Au})-\mathrm{ri}$ a aposits in ultramafic settings (e.g. Fouquet et al., 2010. Along the Mid-Atlantic $\mathrm{ni}_{\mathrm{z}}$, these systems were extensively studied through mineralogical (Hannington et :1., :995; Marques et al., 2006), geochemical (Charlou et al., 2002; Rouxel et al., 2004a) or tectonic approaches (McCaig et al., 2007). However, due to restricted access to the sc floor on which the vertical dimension is rarely accessible, ultramafic-hosted mint:alized systems have been mainly studied in two dimensions preventing recognition of elemental distribution below the venting site. Hence, this inhibits the complete understanding of the hydrothermal processes forming these systems.

Fossil mineralized systems outcropping on-land represent good opportunities to decipher these processes. Ultramafic-hosted systems have been recognized worldwide in the Bou Azzer ophiolite in Morocco (Leblanc and Billaud, 1982), in Cyprus (Foose et al., 1985; Talhammer et al., 1986), in the Northwestern American Cordillera (Foose, 1985; Candela et al., 1989), in the Eimeshan igneous province in China (Song et al., 2003), in the Outukumpu thrust belt in Finland (Peltonen et al., 2008), in the Urals (Nimis et al., 2008; Maslennikov et al., 2017) and in the Platta nappe (Dietrich, 1972; Coltat et al., 2019b). However, for the most part, the primary extensional structures have been disturbed during subsequent deformation 
and metamorphism and the metallic stock has been locally partially reworked. In some cases, the origin of the mineralization is hard to retrieve (Foose, 1985; Talhammer et al., 1896; Song et al., 2003).

In the Platta nappe, Coltat et al., (2019b) recognized a fossil Jurassic ultramafic-hosted black smoker-like system. The overall geometry of this Marmorera-Cotschen hydrothermal system (MCHS) has been preserved from the Alpine overprint. Also, the structural relationships between mineralization, mafic intrusions and detachment fault can be restored. We propose here, based on this geometry, to evaluate the elemental distribution at different structural positions, i.e. at distinct paleo-depths below the detachment, through in-situ LA-ICPMS on metal-bearing phases (chalcopyrite, pyrrhotite, magnetite) and 'wh'e rock geochemistry. The geochemical signatures of the MCHS are compared with the enes reported at present-day seafloor massive sulfides (SMS) to better decipher the $\mathrm{r}$ ro ${ }^{\infty}$,es that occur during the ascent of hydrothermal fluids. On this basis, we propose nat the mineralizing fluids mixed with seawater within the host serpentinites on their way ur to the seafloor.

\section{Geological setting}

The Platta nappe is located in the southeastern part of the Swiss Alps (Grisons' canton) and belongs to the South Pennine Alpine units (figure 1A, B). It represents an ophiolite formed during the openin , $^{c}$ the Alpine Tethys basin during the Jurassic. During this period, E-W mantle exhumat U. $_{1}$ was accommodated along detachments faults (figure 1C, Froitzheim and Manatschal, 15.96, Ipin et al., 2019) and accompanied by mafic magmatism (Desmurs et al., 2002, Am^nn เ: al., 2020). U-Pb dating on zicon grains in gabbroic bodies from the Platta nappe ielied an age of 161 1 Ma (Schaltegger et al., 2002). As the magmatic budget in the 1 'atta nappe was low, serpentinized mantle rocks commonly crop out at the surface where they are covered by mafic extrusives or post-rift sediments (figure 1B, Dietrich, 1970; Epin et al., 2019). As such, the Platta nappe corresponds to an "amagmatic ophiolite" rather than to a Penrose-type ophiolite (i.e. it lacks of a continue and complete oceanic crust). The end of the rifting period was marked by deposition of the Radiolarian Chert Formation. During the Cretaceous, the subduction of the European plate beneath the African plate led to the closure of the former Alpine Tethyan realm. The continental collision implied crustal thickening through W-NW-vergent nappe stacking (D1 phase, Froitzheim et al., 1994). The Platta nappe was only affected by a low-temperature prehnite-pumpellyite metamorphism $\left(<300^{\circ} \mathrm{C}\right.$; Dunnoyer de Segonzac and Bernoulli, 1976; Ferreiro-Mahlmänn, 1995). During the Late Cretaceous, a D2 extensional Alpine phase occurred. It produced top- 
to-the-east to southeast normal faults (Froitzheim et al., 1994). This event is poorly constrained in the Platta nappe (Epin et al., 2019, Coltat et al., under revision). During the Cenozoic, N-S-oriented shortening (D3 phase) resulted in the formation of large-scale E-W folds and N-vergent thrusts (Epin et al., 2017).

Extensional tectonics during Jurassic mantle exhumation was accompanied by intense fluid circulation. This is recorded through i) hydration of primary mantle rocks (i.e. serpentinization) under retrograde conditions (Müntener et al., 2010), ii) alteration of mafic rocks (e.g. rodingitization of mafic intrusions and epidotization-chloritization of mafic extrusive rocks, Amann et al., 2019), iii) formation of minerslized systems (Dietrich, 1972; Perseil-Latouche et al., 1989; Coltat et al., 2019b) and iv) crnor.ation of serpentinites and basalts (Coltat et al., 2019a, b). HT ultramafic-hosted minialized systems have been recognized in the Platta nappe (Marmorera-Cotschen $a_{1} \cdots$ ) in the vicinity of a Jurassic extensional detachment (figure 1D, E). Coltat et $: 1 .(?, 019 \mathrm{~b}$ ) interpreted this mineralized system as an equivalent to the root zone of present da, ultramafic-hosted black smokers as those active at slow-spreading Mid-Oceanic R d es. These authors showed that the overall system underwent a certain amount of ... in internal deformation. This allows the Jun sic extensional structures to be restored and the mineralized system to be studied in its $\mathrm{u}$. disturbed geometry. 


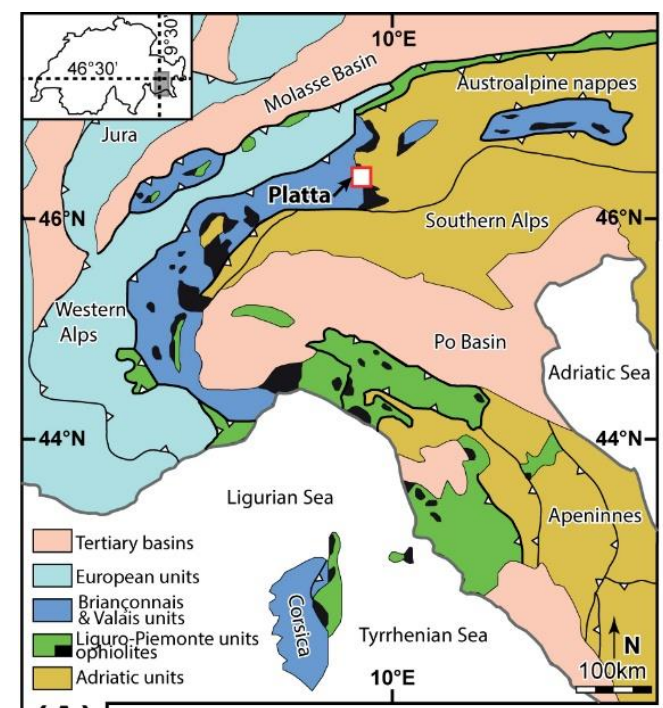

(A)
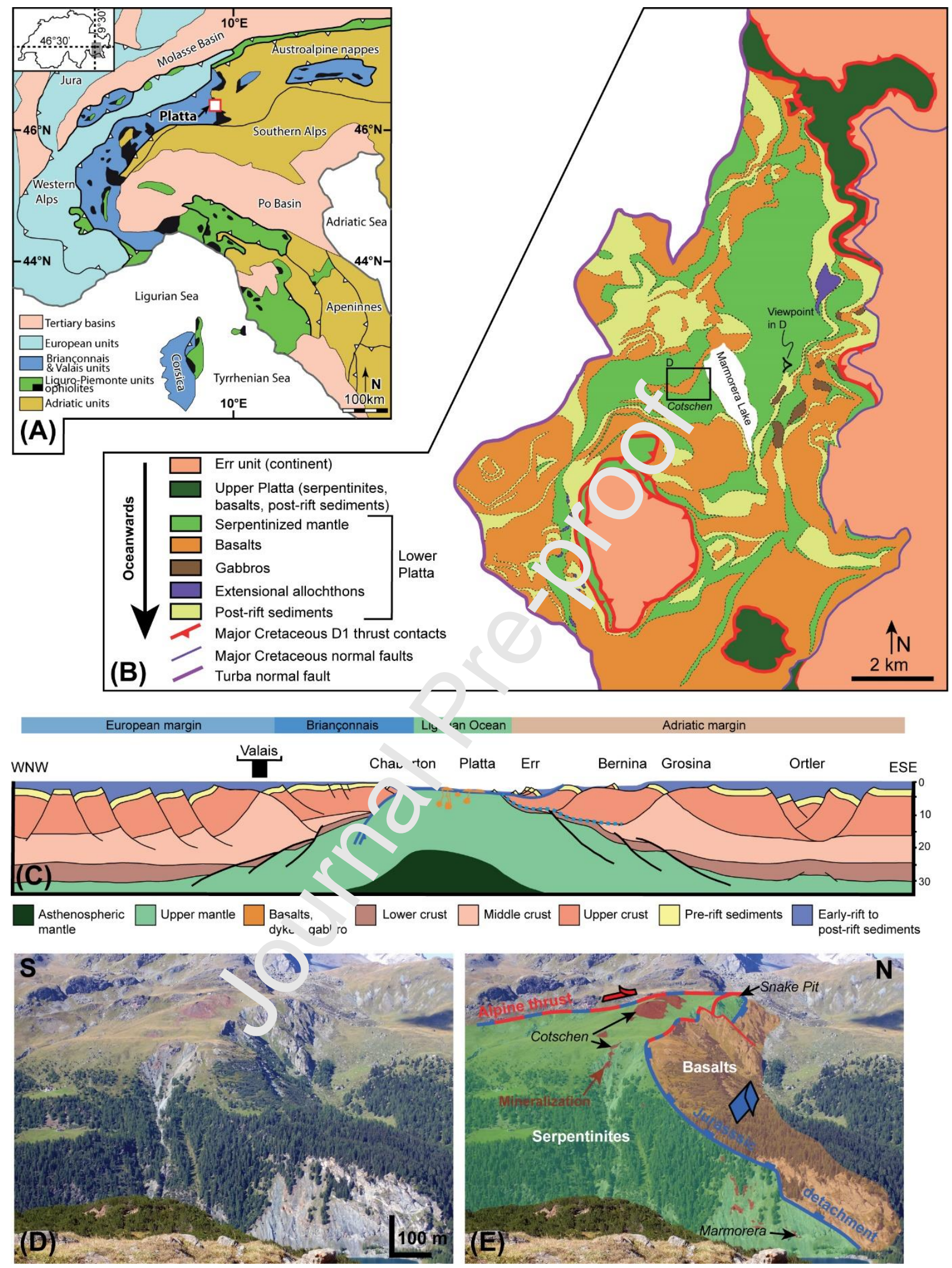

Figure 1. (A) Simplified map showing the main paleogeographic units of the Central and Western Alps and the Apennines. The inset in the top-left corner displays the location of the investigated site in Switzerland. (B) Geological map of the Platta nappe (modified after Schaltegger et al., 2002) showing the Marmorera Cotschen area displayed in D (black inset). 
(C) Restored cross section showing mantle exhumation beneath the Adriatic plate during the Jurassic WNW-ESE-oriented opening of the Alpine Tethys Ocean (after Pinto et al., 2015). (D) Westwards view of the Marmorera-Cotschen hydrothermal system cliff (viewpoint shown in B) and (E) interpreted line-drawing. Modified after Coltat et al. (2019b)

\section{Sampling, Samples and Analytical methods}

\subsection{Field description}

Coltat et al. (2019b) investigated the Marmorera-Coschen hydrothermal system. A brief description of their results is given here. The MCHS is hosted in the serpentinized footwall of a top-to-the-W detachment juxtaposing basalts onto serpentir.'s (figure 1D, E, 2A). The system outcrops noticeably well in 3D over a height $c_{f} 610 \mathrm{~m}$. The $\mathrm{Fe}-\mathrm{Cu}-\mathrm{Ni}-\mathrm{Co}-\mathrm{Zn}$ mineralization is carried by sulfides (mainly chalcopyrite pyr hotite, pentlandite, sphalerite), oxides (magnetite) and is associated with coeval $\mathrm{Fe}-\mathrm{C}_{2}$-silicates (ilvaite, hydrogarnet and diopside). As a rule, where mineralization occurs, $v^{\circ}$, rimary lizardite is replaced by $\mathrm{Fe}$ antigorite and/or greenalite.

The site of Cotschen represents the bottr... or the system, at around $150 \mathrm{~m}$ below the paleo detachment (figures 1D, E, 2). It is mac of serpentinites extensively replaced by $\mathrm{Fe}-\mathrm{Ca}-$ silicates, sulfides (sphalerite, chalcopyı 'te, pyrrhotite) and magnetite. Locally, Fe-Ca-silicates veins form a stockwork. At other p.ares, Fe-Ca-silicates are absent and the mineralization is carried by an assemblage of ulthies and oxides in various proportions forming the semimassive sulfides facies. At Totschen, the end-members of this facies are either sulfide veins (mainly pyrrhotite wh ninor chalcopyrite) crosscutting serpentinite or serpentinite replaced by magnetitc ' $\mathrm{v} 1 \mathrm{~h} \mathrm{r}$. inor sulfides (figure $2 \mathrm{C}$ ).

The mineralization of Mrarmorera is located at around $80 \mathrm{~m}$ below the detachment (figures 1D, $\mathrm{E}, 2)$. The hydrothermal facies from this site are the most diversified among those found at the MCHS (figure 2C). The mineralization is associated with a mafic dyke (figure 2). Close to the dyke, serpentinite is locally almost completely replaced by a $\mathrm{Cu}$-rich assemblage of chalcopyrite and minor isocubanite. Magnetite, pyrrhotite and pentlandite occur together with diopside and are embedded in the chalcopyrite groundmass. Serpentinite clasts locally remain (figure 2C). Where hydrothermal alteration is less intense, a semimassive sulfides facies occurs. It is comprised of pyrrhotite, magnetite and minor chalcopyrite veins. In the serpentinite groundmass, magnetite grown at the expense of Cr-rich spinel is common (figure 2C). Pyrrhotite is locally associated with this magnetite. Fe-Ca-silicates occur in the outer part 
of the mineralization. They are comprised of either diopside or magnetite forming infilling pockets and veins, respectively (figure 2C). Ilvaite occurs as veins associated with diopside and minor chalcopyrite and magnetite. Magnetite also occurs in the serpentinite groundmass where it rims spinel relics. Locally, ilvaite rim develops around this magnetite. Barren serpentinite consists of lizardite-rich serpentinite which contains micrometer-sized magnetite and pentlandite grains (figure 2C).

The Snake Pit mineralization is at around 30m below the detachment (figure 2). There, Fe-Casilicates vanish (figure 2B) and the mineralization is made of euhedral pyrite forming disseminated grains or aggregates (figure 2C). Inclusions ef chalcopyrite, pyrrhotite and sphalerite locally occur in pyrite. These phases together with r^ntla ndite are also encountered around pyrite grains (figure $2 \mathrm{C}$ ). The mineralization is rens alcite veins forming fracture-filling ophicalcites. Locally, chalcopyrite is as $o^{i^{2 t}} \mathrm{~d}$ with calcite suggesting that the copper stock has been slightly remobilized during car onation (figure 2C).

\subsection{Sampling strategy}

Several samples have been collected at c.ch of the three levels depicted above as representative of the variability of hya ${ }^{\prime}$ '.ermal rocks (figure 2C). They represent either serpentinites extensively replaced by Fe-Ca-silicates and/or mineralization (sulfides and oxides) or serpentinites crosscut by ma ralized veins (i.e. stockwork structure). The former contains more metal-bearing ph tses, hence it was mainly investigated. At Snake Pit, the mineralization type differs and 1 expressed as disseminated sulfides. Also, barren serpentinite has been collected to yield ti. a fi st-order geochemical signature of the host rocks.

The variability of hya th. nal rocks reported at the MCHS is more important than the one expected at present-day '.ydrothermal venting sites where massive sulfides rather occur (i.e. $\mathrm{Fe}-\mathrm{Ca}$-silicates-rich hydrothermal facies have never been recovered in present-day settings). At the seafloor, where fluids vent, massive sulfides directly precipitate from hydrothermal fluids (i.e. chimneys, sulfide mounds), whereas at the MCHS replacement process of serpentinite by mineralization is the main process of metal enrichment. Therefore, a direct comparison of the geochemical signatures of the two systems (i.e. the MCHS and present-day SMS) would be meaningless. Thus, we first document the element mobilities associated with hydrothermal alteration and mineralization formation at the MCHS. Then we compare these signatures to the ones of present-day deeply altered and mineralized rocks where replacement processes occur. 
Noticeably, at the MCHS we do not have evidence of exhalative system. Also, the precise location of the paleo-seafloor remains speculative and the exact basalt thickness is unknown. Therefore, we cannot precisely define the paleodepth of the MCHS. As a consequence, in figure $2 \mathrm{~B}$, present-day black smokers represent the termination of the hydrothermal system without spatial continuation with the MCHS. This justifies the horizontal white area in figure 2B. However, we assume that fluids would eventually have vented at the seafloor where SMS likely formed. The strategy adopted in this study was to document the distribution of selected elements on the vertical scale as markers of the processes likely to occur during hydrothermal fluid flow.

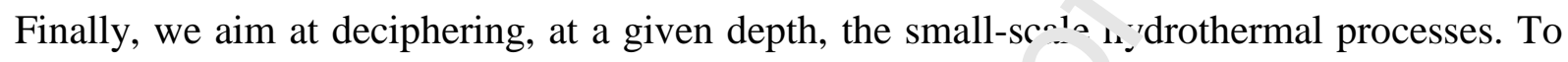
resolve this point, we paid a special attention to the Marmu $\cdots$ a section as it displays the largest variety of mineralization types.

\subsection{Samples}

Whole rock chemical analyses on both minerali er a nd barren samples coupled to in-situ LAICPMS analyses on metal-bearing phases $\left(\mathrm{ch}_{n}{ }^{1}\right.$ copyrite, pyrrhotite and magnetite) have been carried out.

At the bottom of the system (i.e. Cotsci an), two samples of the Fe-Ca-silicates facies have been selected (Cot18_40a and Cit18_46b, figure 2C). Both represent serpentinites extensively replaced by an assemilage of $\mathrm{Fe}-\mathrm{Ca}$-silicates associated with minor sulfides. The sample Cot18_46b displays $t_{1}$ - highest degree of alteration. At the same place, two samples of semimassive sulfides sclus have been collected (figure 2C). They correspond to the endmembers of this inc, representing either a pyrrhotite-rich sample (Cot18_71) or a magnetite-rich with mis_.. sulfides sample (Cot16_61, figure 2C).

At Marmorera, four samples have been collected perpendicular to a mafic dyke (figure 2C). They correspond to the barren serpentinites (Mar16_31), the Fe-Ca-silicates facies (Mar18_39), the semimassive sulfides facies (Mar18_31a) and the $\mathrm{Cu}$-rich massive sulfides facies (Cu-rich MS, Mar16_35). An additional sample in the Cu-rich MS (Mar16_34) has been selected for the determination of the whole rock composition. It corresponds to the most mineralized $\mathrm{Cu}$-rich sample (table 2). 
At the top of the system (Snake Pit), four samples have been selected (figure 2C, table 1). Samples Cot16_49a and Cot16_52 represent the least and the most mineralized sample, respectively (figure $2 \mathrm{C}$ ). The four samples also display variable intensity of carbonation.

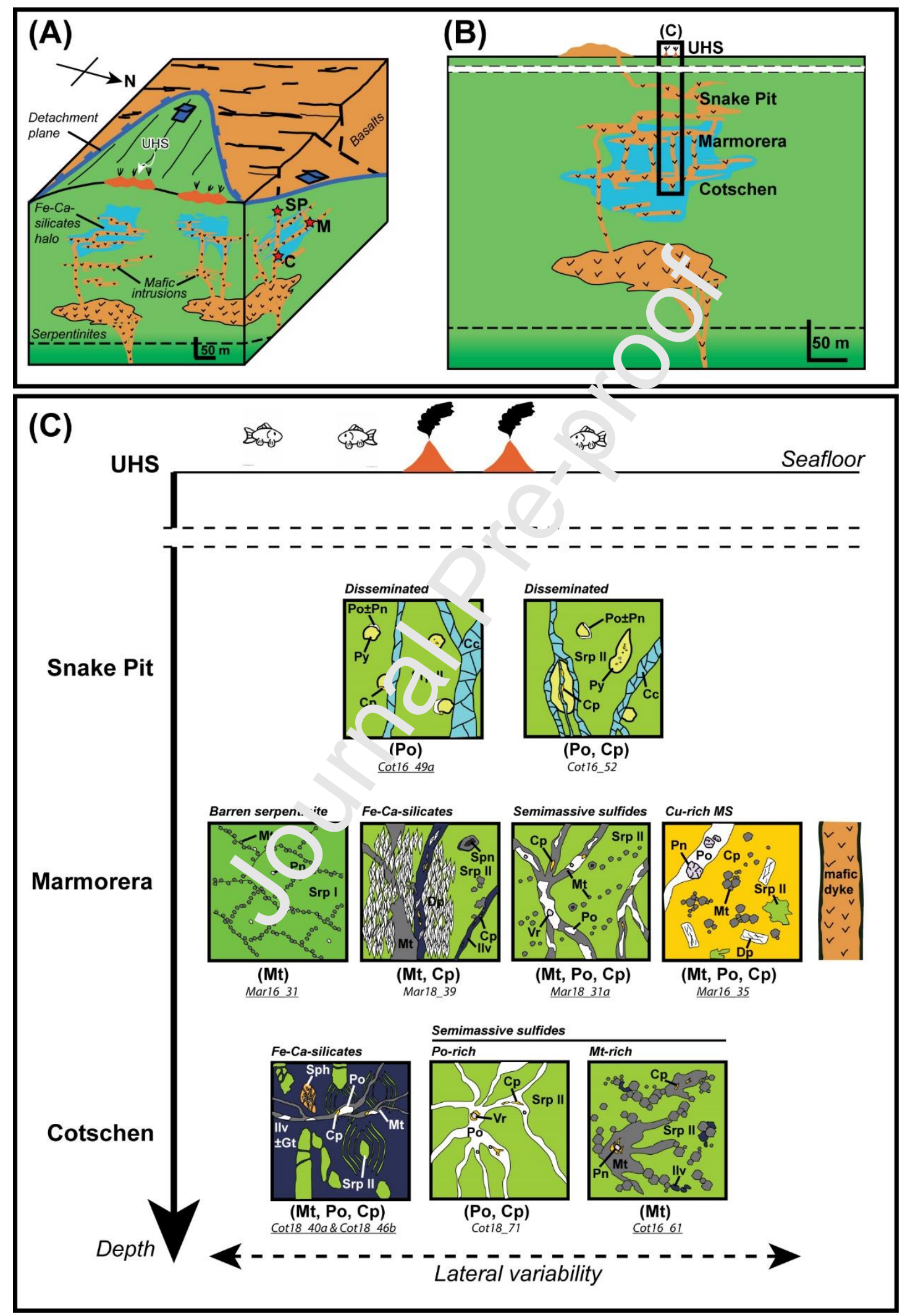


Figure 2. (A) Schematic 3D block diagram showing a detachment fault exhuming mantle rocks beneath a mafic extrusive crust (from Coltat et al., 2019b). Location of the investigated sites (Cotschen, C; Marmorera, M and Snake Pit, SP) at different depths beneath the detachment. (B) Reconstructed section across the mineralized footwall of the paleo detachment of Marmorera-Cotschen. The different sites have been projected from their horizontal position on a vertical section consistently to their paleo-depth. Present-day ultramafic-hosted black smokers (UHS) are displayed at the seafloor. (C) Hydrothermal facies investigated at different structural positions (Cotschen, Marmorera, Snake Pit) through LA-ICPMS analyses. Thin section schemes are unscaled. Below each scheme, the name of the sample and the metal-bearing phases analyzed by LA-ICPMS $\omega_{1}$ given. Underlined samples have been also analyzed through whole rock geochemistry. (' $b=$ chalcopyrite, Po=pyrrhotite, Mt=magnetite, $\quad$ Pn=pentlandite,$\quad P y=$ pyrite,$\quad V r=v i o l a$ ite,$\quad$ Sph=sphalerite,$\quad I l v=i l v a i t e$, Gt=hydro-andradite, $D p=$ diopside, Srp=serpentine.

\subsection{Analytical methods}

Whole rock quantitative chemical data were a : qu ${ }^{*}$, d using X-ray fluorescence at the Marine Geosciences department at Ifremer inst tut' (Pıouzané, France). Analyses were conducted with a wavelength dispersive X-ray fluorescu. ice spectrometer (WD-XRF; BRUKER AXS S8 TIGER) on fusion beads or compre ${ }^{\circ}$, pellets for major and trace elements, respectively. Fusion beads were prepared as fo". 1 w. $\mathrm{g}$. For sulfide-rich rocks $0.3 \mathrm{~g}$ of dried sample $\left(70^{\circ} \mathrm{C}\right)$ was placed in a Pt-Au crucih e vith 7g spectroflux 161 (Li2B4O7 90\% + LiNO3 10\%; Claisse-Malvern Panlaytical). ? $3 \mathrm{~g}$ of $\mathrm{NaBr}$ with $3 \mathrm{~g}$ of spectroflux 161 and $3 \mathrm{~g}$ of spectroflux 106 (Li2B4O7 85\% + Li $2 \mathrm{U}^{2}$ 15\%; Johnson Matthey) was then added and the Pt-Au crucible was heated progressiveı, trom room temperature to $500^{\circ} \mathrm{C}$ for $1 \mathrm{~h}$ in an electric furnace before fusion at $1000^{\circ} \mathrm{C}$. This method prevents sulfur loss present in sulfides during fusion at $1000^{\circ} \mathrm{C}$. For silicate rocks, $0.5 \mathrm{~g}$ of calcined sample was placed in a Pt-Au crucible with $9 \mathrm{~g}$ of spectroflux 120A (Li2B4O7 90\% - LiF 10\%, SPCSciences) and 500 $\mu \mathrm{L}$ of a $250 \mathrm{~g} / \mathrm{L}$ solution of $\mathrm{LiBr}$ (Merck) no-wetting agent was added. The fusion was performed at $1050^{\circ} \mathrm{C}$ in an electric furnace. Gold was determined after separation on an ion-exchange filter following the methodology described in Etoubleau et al. (1996). After data acquisition, measured net peak intensities corrected from inter-element effects were converted into concentrations using calibration curves generated from the analysis of certified geochemical standard powders prepared following the same protocol and measured under identical analytical conditions. Calibration curves were established using certified rock materials from the Centre de 
recherches pétrographiques et géochimiques (e.g. BE- N, IF- G), the Canadian certified reference materials project (e.g. UM- 1, UM- 2, UM- 4, WMG- 1, CCU-1 set, CZN set, KC1a, PTC-1a, PTM-1a, RTS-1, RTS-2, RTS-3, MP-1, MP-2, WMS-1a ) and the Geological survey of Japan (e.g. JB- 3, JCFA- 1, JLs- 1, JSD- 2). Reference serpentinite (HARZ01GeoPT) and Cu-rich sulfide matrix (CCU1d) were analyzed as unknowns using the same methods as for the silicate and sulfur samples, respectively (appendix 6).

Prior to LA-ICPMS analyses, the sulfides and oxides were analyzed using a Cameca SX100 Electron Probe Micro Analyser (EPMA) at Microsonde Ouest (Plouzané, France) to give composition used for internal standard. Analyses were corducted using an accelerating voltage of $15 \mathrm{kV}$ and a beam current of $20 \mathrm{nA}$. A beam diame ${ }^{\mathrm{r} r}$ oi 5 and $1 \mu \mathrm{m}$ was used for analyses on sulfides and oxides, respectively. Natural sulfides a oxides standards have been used for standardization. Counting time for sulfides was $1 \mathrm{c}^{\mathrm{f}}$, $\mathrm{r} \mathrm{S}, \mathrm{Fe}, \mathrm{Co}, \mathrm{Cr}, \mathrm{Ni}$, Ti and $\mathrm{Mn}$; 20s for $\mathrm{Cu}, \mathrm{Zn}$, and $\mathrm{Se}$; 60s for As and V. For $\mathrm{m} \iota \mathrm{gh}$ tıe, counting time was 10 s for all element except $\mathrm{Zn}$ was 20s.

After optical microscopy and EPMA analv is r rected samples were analysed by laser ablation quadrupole inductively coupled slas ma mass spectrometry (LA-Q-ICPMS) at Trinity College, Dublin. Trace element analysis was carried out using a Teledyne-Cetac G2 193 nm wavelength ArF excimer laser ablat ${ }^{\prime}$ n s, stem with a HelEx 2-volume cell, where ablation occurs. The laser is coupled via ${ }^{+} \mathrm{tr} \approx$ ely narrow bore PEEK tubing and a Teledyne-Cetac ARIS rapid sample-introductir $n$ s, stem to a Thermo-Fischer iCap Qs quadrupole ICPMS. This analytical set-up is ideal for rapid elemental mapping. For spot analyses an in-house adjustable-volume signa -sı oothing device was used, which permitted the use of a wide range of laser repetition. 'Ttes.

The primary standard material used is USGS MASS-1 sulphide (Wilson et al., 2002). UQAC sulphide micropowder pellet (Onuk et al., 2017), MUL sphalerite (Onuk et al., 2017) and basalt glass BCR-2G were the secondary standards employed (appendix 7). Conventional standard-sample bracketing was used during spot analysis. Data reduction was performed using the Iolite data reduction software (Paton et al., 2011). After the data treatment, each individual integration was checked for where spikes in the signal due to microinclusions or mechanical mix between distinct sulfide phases (e.g. change of phase with increasing ablation depth) were clearly recognized, the analyses were dismissed to avoid the effect of mineralogical inclusions in the analyzed phase.Average mineral Fe composition data from 
EPMA analyses were used as the necessary internal standard for the processing of the spot trace element data acquired via LA-ICP-MS.

\section{Results}

The whole rock and single grain chemical compositions are given in tables 1 to 5 and are represented in figures 3 to 13 for selected elements. The extensive data base is presented as discriminants diagrams in appendix 1 and box plots in appendixes 2 to 4 .

Although Fe-Ca-rich metasomatism was coeval to mineralization at the MCHS, we differentiate between the two processes. Throughout the manuscript, "altered rocks" refer to serpentinites replaced by Fe-Ca-silicates (and locally associate ivith minor sulfides), whereas "mineralized rocks" correspond to serpentinites replaced by in tai-bearing phases (sulfides and oxides). The most altered rocks do not necessarily corr ${ }_{\mathrm{v}_{1}}$ - Ond to the most mineralized but rather reflect higher degree of hydrothermal alteration $u^{n}$ del $w$ unt by the serpentinites. 
Table 1. Whole rock major and trace element compositions of barren, altered and mineralized rocks from the MCHS and averaged compositions of rocks at the present-day ultramafic-hosted Rainbow hydrothermal site.

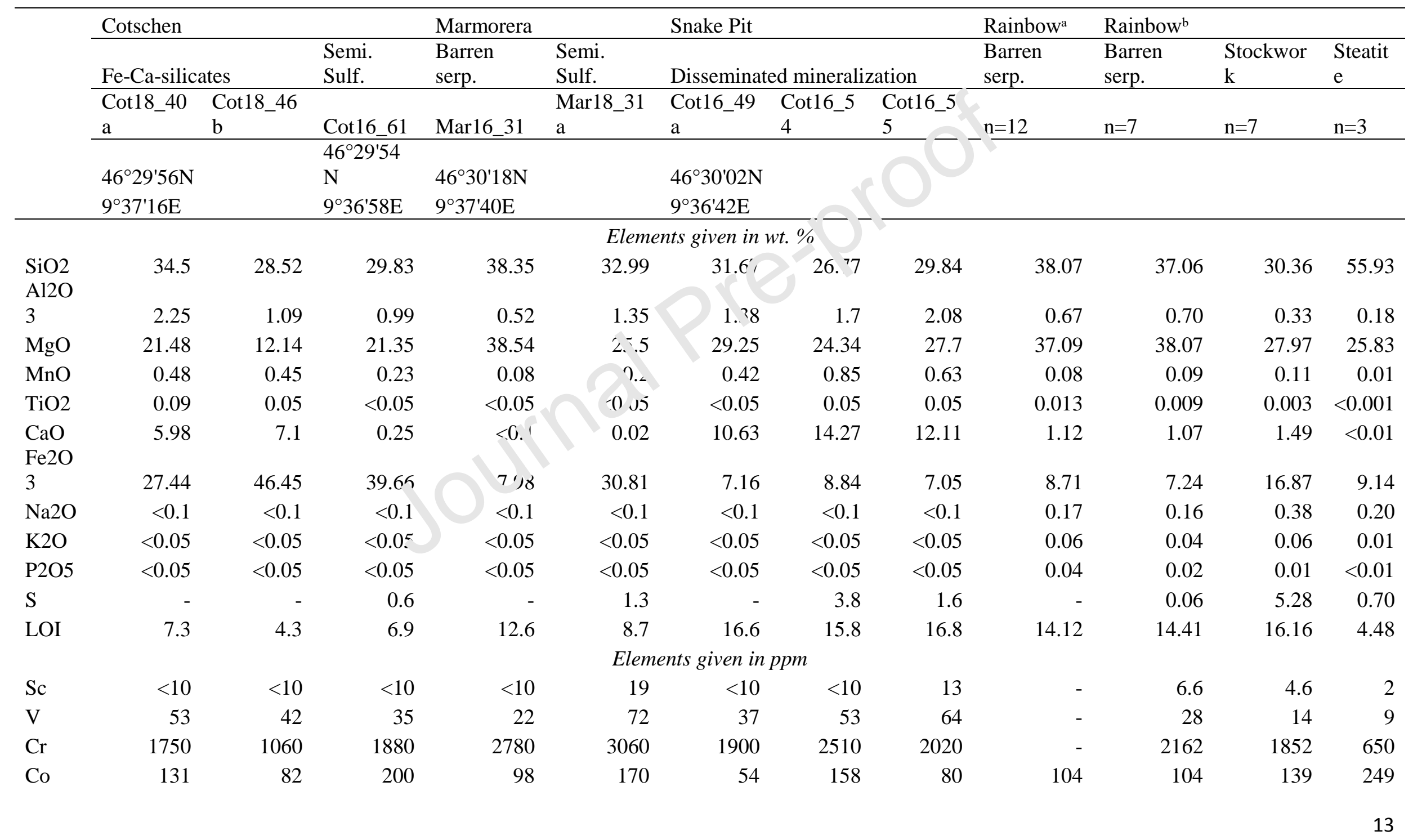


Journal Pre-proof

\begin{tabular}{|c|c|c|c|c|c|c|c|c|c|c|c|c|}
\hline $\mathrm{Ni}$ & 1450 & 203 & 1090 & 2250 & 2430 & 1170 & 1890 & 1750 & 1846 & 1658 & 1022 & 652 \\
\hline $\mathrm{Cu}$ & 1380 & 3900 & 11700 & 48 & 270 & 11 & 5600 & 1140 & 20 & 542 & 1421 & 257 \\
\hline $\mathrm{Zn}$ & 142 & 757 & 113 & 21 & 146 & 38 & 3440 & 504 & 127 & 149 & 527 & 222 \\
\hline As & $<10$ & $<10$ & $<10$ & $<10$ & $<10$ & $<10$ & $<10$ & $<10$ & 6.1 & 3.4 & 1.9 & 0.65 \\
\hline $\mathrm{Sr}$ & $<10$ & $<10$ & $<10$ & $<10$ & 12 & 185 & 192 & 117 & 205 & 74 & 219 & $<1$ \\
\hline $\mathrm{Y}$ & $<5$ & $<5$ & $<5$ & $<5$ & $<5$ & $<5$ & $<5$ & $<!$ & 0.44 & 1 & 1 & $<0.5$ \\
\hline $\mathrm{Zr}$ & 10 & 11 & 8 & 5 & 7 & 5 & 6 & s & - & 5.7 & 4.4 & 2 \\
\hline $\mathrm{Ag}$ & - & - & $<50$ & - & - & - & $<7$ & - & - & $<0.5$ & 0.93 & $<0.5$ \\
\hline $\mathrm{Sb}$ & $<20$ & $<20$ & $<20$ & $<20$ & $<20$ & $<20$ & ניחי & $<20$ & 0.14 & 0.6 & 0.47 & 0.10 \\
\hline $\mathrm{Ba}$ & $<100$ & $<100$ & $<100$ & $<100$ & $<100$ & $\langle:(C)$ & $<160$ & $<100$ & 0.9 & 2 & 4.2 & 2 \\
\hline $\mathrm{Au}$ & - & - & $<0.1$ & - & & & $<0.1$ & - & - & 0.004 & 0.044 & 0.011 \\
\hline $\mathrm{La}$ & $<20$ & $<20$ & $<20$ & $<20$ & 20 & $<20$ & $<20$ & $<20$ & 1.1 & - & - & - \\
\hline
\end{tabular}

a from Andreani et al. (2014)

${ }^{b}$ from Marques et al. (2007)

Abbreviations: Semi. Sulf.=semimassive sulfide .. . at "en serp.=barren serpentinite. "-"=element not measured. 
Table 2. Major and trace element compositions of the Cu-rich MS at the MCHS compared to averaged compositions of selected present-day SMS (from Fouquet et al., 2010 and references therein).

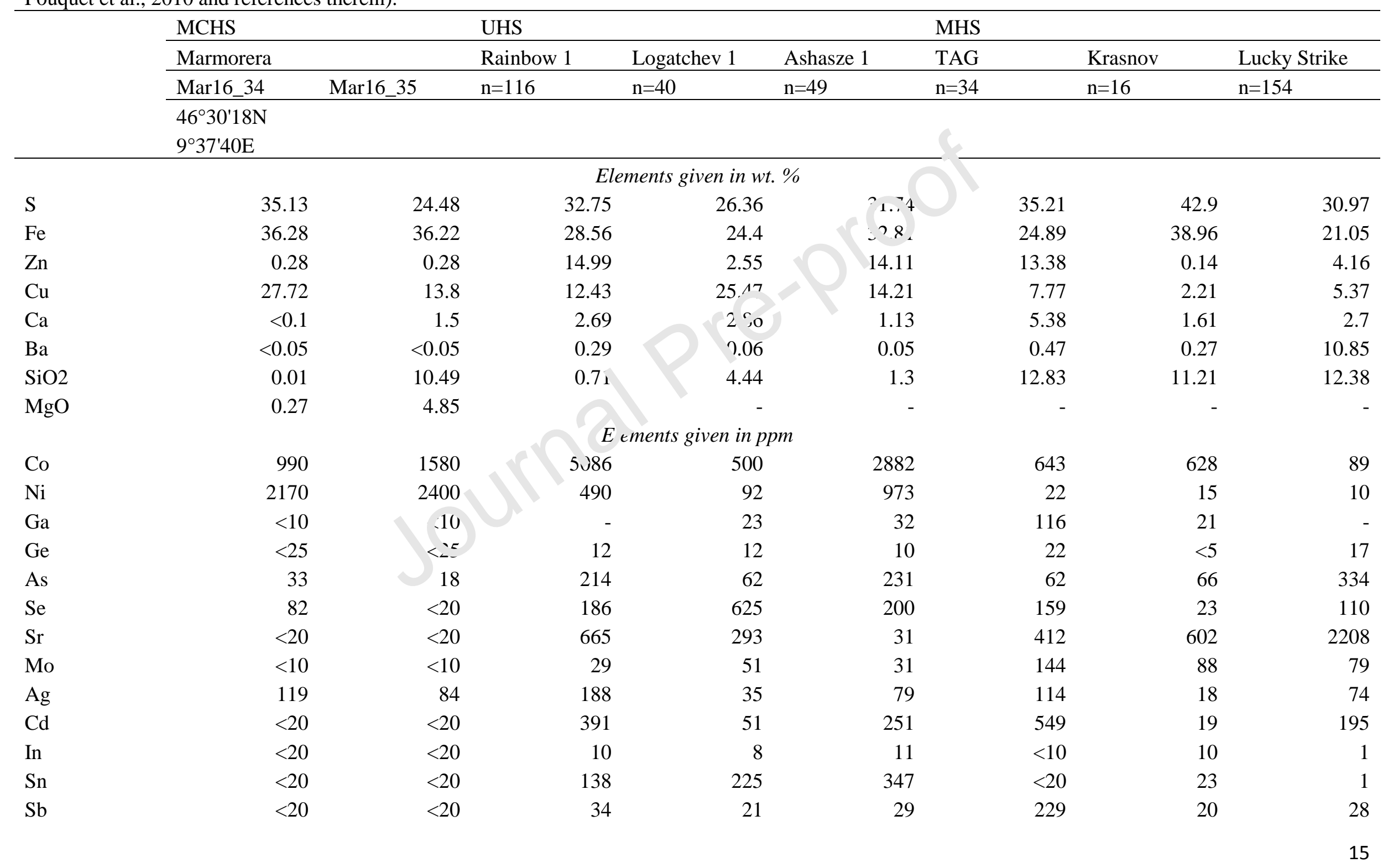




\section{Journal Pre-proof}

\begin{tabular}{lrrrrrrr}
$\mathrm{Au}$ & $<0.1$ & 0.8 & 5.1 & 8.4 & 6.3 & 1.4 & 1.1 \\
$\mathrm{~Pb}$ & $<1000$ & $<1000$ & 342 & 209 & 350 & 0.3 \\
$\mathrm{U}$ & $<20$ & $<20$ & 11 & 14 & 7 & 9 & 70 \\
\hline$"-"=$
\end{tabular}

"-"=element not measured. UHS=Ultramafic-hosted hydrothermal systems. MHS=Mafic-hosted hydrothermal systems 


\section{Journal Pre-proof}

Table 3. LA-ICPMS trace element compositions of chalcopyrite (in ppm) of the fossil MCHS and present-day VMS.

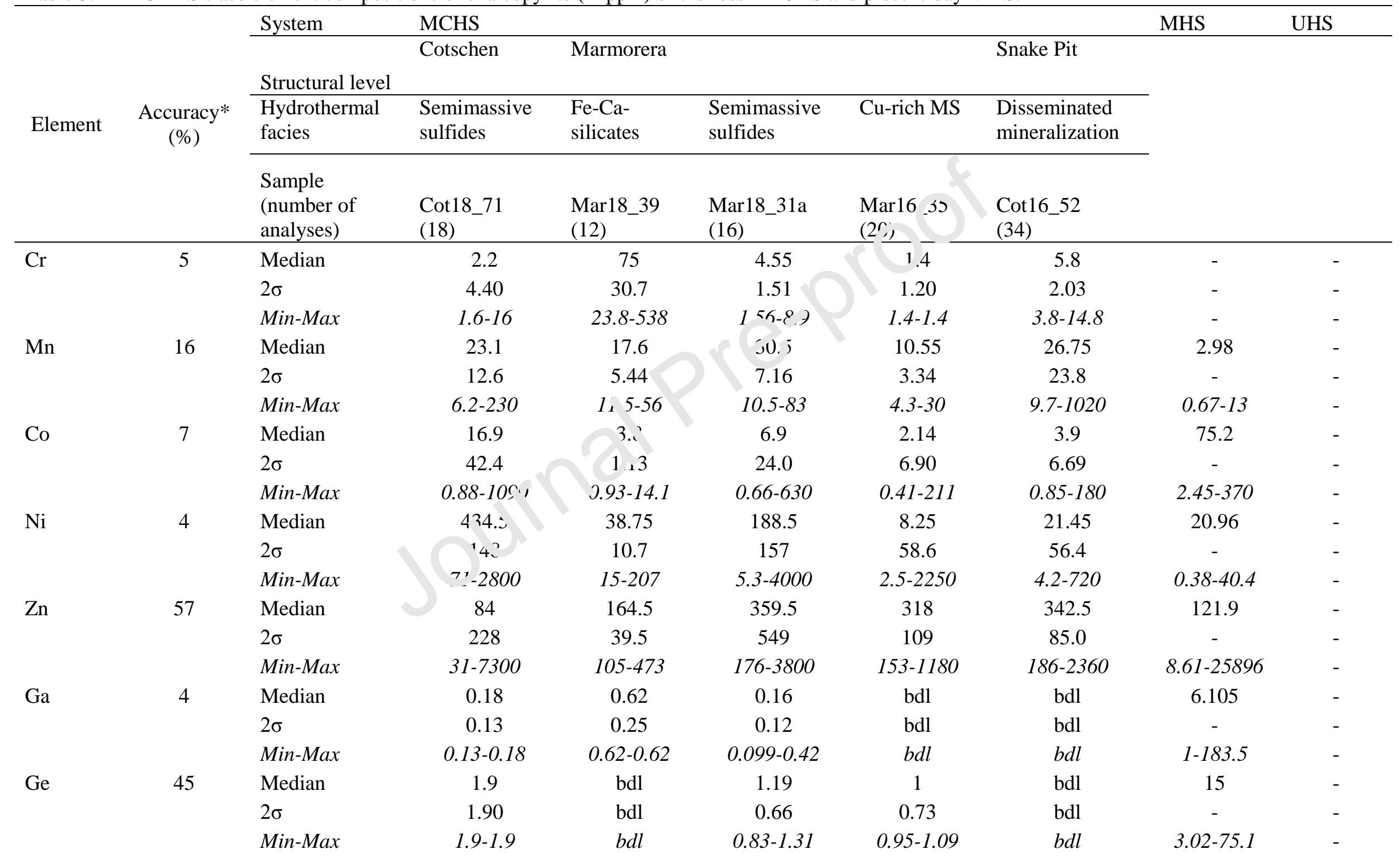


Journal Pre-proof

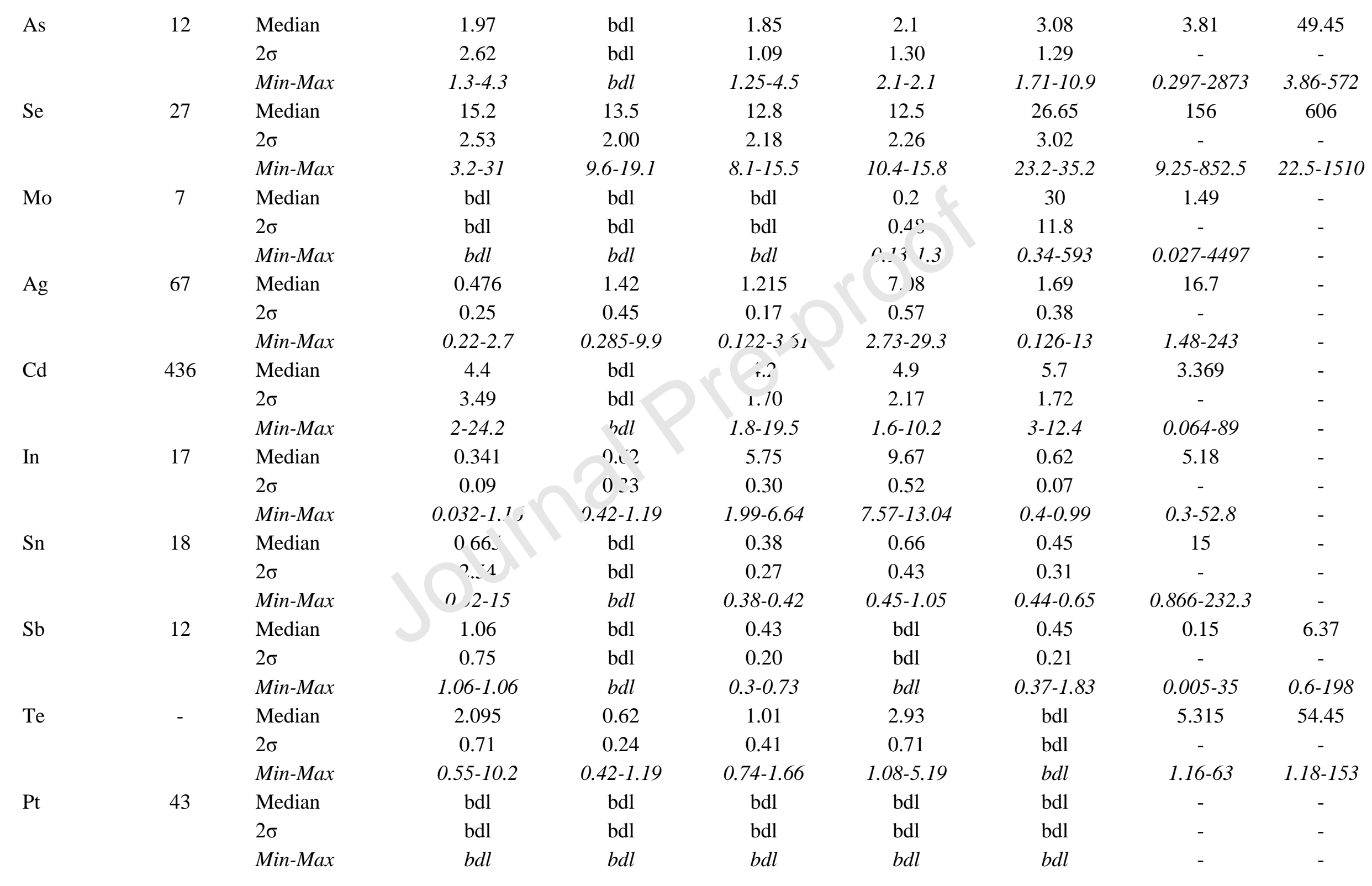




\begin{tabular}{|c|c|c|c|c|c|c|c|c|c|}
\hline \multirow[t]{2}{*}{$\mathrm{Au}$} & - & Median & bdl & bdl & 0.49 & bdl & 0.093 & 0.314 & 2.035 \\
\hline & & $2 \sigma$ & bdl & bdl & 0.89 & bdl & 0.09 & - & - \\
\hline \multirow[t]{2}{*}{$\mathrm{Pb}$} & 10 & Median & 3.925 & 6.48 & 5.175 & 2.79 & 6.7 & 0.383 & - \\
\hline & & Min-Max & $0.69-8.58$ & $1.81-14.5$ & $1.02-8.89$ & $0.56-8.6$ & $0.46-20.3$ & $0.06-2.55$ & - \\
\hline \multirow[t]{2}{*}{$\mathrm{Bi}$} & 13 & Median & 0.063 & 0.108 & 0.234 & 0.065 & 0.073 & 0.106 & - \\
\hline & & $2 \sigma$ & 0.09 & 0.02 & 0.06 & 0.05 & 0.02 & - & - \\
\hline
\end{tabular}

Values below the limits of detection are not considered. Abbreviations: bdl=below the detction 1: nit

MHS data are from Wohlgemuth et al., 2015; Melekestseva et al., 2017; Grant et al., 2018; ' ua. $\epsilon$ al., 2018.

UHS data are from Wohlgemuth et al., 2015.

*Average of the differences measured between the known element content of the ant ana ional standard BCR or MUL1 (As and Se) and the content obtained running the standard as an unkown (relative error). 
Table 4. LA-ICPMS trace element compositions of pyrrhotite (in ppm) of the fossil MCHS

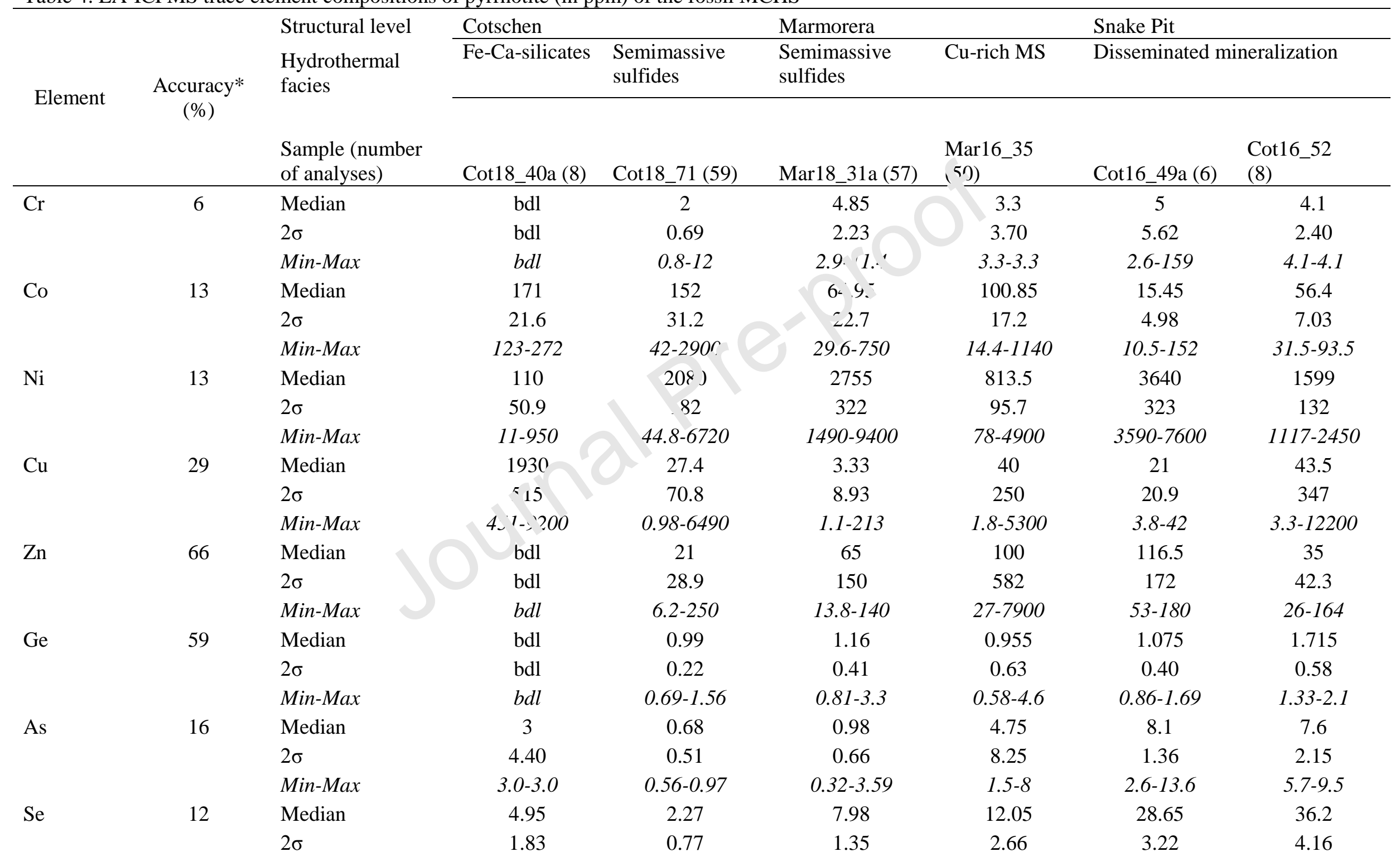




\section{Journal Pre-proof}

\begin{tabular}{|c|c|c|c|c|c|c|c|c|}
\hline \multirow{3}{*}{$\mathrm{Ag}$} & & Min-Max & $3.8-5.6$ & $1.13-18$ & $6.2-10.4$ & $8-18.2$ & $22.3-40.9$ & $31.6-44$ \\
\hline & \multirow[t]{2}{*}{64} & Median & 0.97 & 0.306 & 0.24 & 4.98 & 0.605 & 1.13 \\
\hline & & Min-Max & $0.48-3.42$ & $0.055-0.85$ & $0.065-0.93$ & $1.47-97$ & $0.136-1.73$ & $0.439-2.16$ \\
\hline \multirow{2}{*}{$\mathrm{Sb}$} & \multirow{2}{*}{13} & $2 \sigma$ & bdl & 0.46 & 4.54 & 0.45 & 0.30 & 0.28 \\
\hline & & Min-Max & $b d l$ & $0.135-1$ & $0.86-4.4$ & $0.51-0.53$ & $1.27-1.27$ & $0.49-0.49$ \\
\hline $\mathrm{Pt}$ & 41 & Median & bdl & bdl & 0.015 & 0.095 & bdl & bdl \\
\hline \multirow[t]{3}{*}{$\mathrm{Pb}$} & \multirow[t]{3}{*}{14} & Median & 2.97 & 1.56 & $\angle 2$ & 5.655 & 2.91 & 7.3 \\
\hline & & $2 \sigma$ & 0.59 & 0.26 & ก.39 & 0.94 & 0.61 & 1.31 \\
\hline & & Min-Max & $1.65-8.2$ & $0.399-10 .{ }^{2} 8$ & $0.4,3-8.45$ & $1.74-13$ & $0.71-18.7$ & $3.5-15.6$ \\
\hline \multirow[t]{2}{*}{$\mathrm{Bi}$} & \multirow[t]{2}{*}{43} & Median & 0.043 & 0.0 ) & 0.147 & 0.411 & 0.06 & 0.107 \\
\hline & & $2 \sigma$ & 0.02 & 02 & 0.06 & 0.10 & 0.08 & 0.07 \\
\hline
\end{tabular}

Values below the limits of detection are not considered. Abbre-iati ns . bdl=below the detection limits

*Average of the differences measured between the knowi ele nen content of the international standard BCR or MUL1 (for As and Se) and the content obtained running the standard as an unkown (relative erı or, 
Journal Pre-proof

Table 5. LA-ICPMS trace element compositions of magnetite (in ppm) of the fossil MCHS and present-day VMS (data from Patten et al., 2016)

\begin{tabular}{|c|c|c|c|c|c|c|c|c|c|c|c|c|}
\hline \multirow{3}{*}{$\begin{array}{c}\text { Eleme } \\
\text { nt }\end{array}$} & \multirow{3}{*}{$\begin{array}{c}\text { Accurac } \\
\mathrm{y}^{*}(\%)\end{array}$} & System & MCHS & & & & & & & & & \multirow{2}{*}{$\begin{array}{l}\text { MHS } \\
\text { Hole } \\
1256 \mathrm{D} \\
\text { Hydrother } \\
\text { mal } \\
\text { Magnetite }\end{array}$} \\
\hline & & $\begin{array}{l}\text { Hydrother } \\
\text { mal facies }\end{array}$ & \multicolumn{2}{|l|}{$\begin{array}{l}\text { Cotschen } \\
\text { Fe-Ca- } \\
\text { silicates }\end{array}$} & $\begin{array}{l}\text { Semimass } \\
\text { ive } \\
\text { sulfides }\end{array}$ & $\begin{array}{l}\text { Barren } \\
\text { serpentini } \\
\text { te }\end{array}$ & $\begin{array}{l}\mathrm{Fe}-\mathrm{Ca}- \\
\text { silicates }\end{array}$ & & $\begin{array}{l}\text { Semimass } \\
\text { ive } \\
\text { sulfides }\end{array}$ & & $\begin{array}{l}\text { Cu-rich } \\
\text { MS }\end{array}$ & \\
\hline & & $\begin{array}{l}\text { Sample } \\
\text { (number of } \\
\text { analyses) }\end{array}$ & $\begin{array}{l}\text { Cot18_40a } \\
(31)\end{array}$ & $\begin{array}{l}\text { Cot18_4 } \\
6 \mathrm{~b}(20)\end{array}$ & $\begin{array}{l}\text { Cot16_61 } \\
(20)\end{array}$ & $\begin{array}{l}\text { Mar16_3 } \\
1 \quad(5)\end{array}$ & $\begin{array}{l}\text { Mar18_39 } \\
\text { V (9) }\end{array}$ & C M 1: & $\begin{array}{l}\text { Mar18_3 } \\
12 \\
\text { V (16) }\end{array}$ & GM (24) & $\begin{array}{l}\text { Mar16_3 } \\
5(19) \\
\end{array}$ & \\
\hline \multirow{2}{*}{$\mathrm{Na}$} & \multirow{2}{*}{10} & $2 \sigma$ & 15 & bdl & bdl & bdl & ba: & bdl & 10.9 & 15.7 & 11.6 & - \\
\hline & & Min-Max & $44-44$ & $b d l$ & $b d l$ & $b d l$ & $\dot{\nu d l}$ & $b d l$ & $28.5-80$ & 18.6-387 & $15.4-46$ & - \\
\hline \multirow[t]{3}{*}{$\mathrm{Mg}$} & \multirow[t]{3}{*}{7} & Median & 1120 & 1190 & 472 & 6050 & +33 & 325 & 1111.5 & 1175 & 167 & - \\
\hline & & $2 \sigma$ & $\begin{array}{c}364 \\
167.3-\end{array}$ & $\begin{array}{c}180 \\
89.6-\end{array}$ & 393 & $\begin{array}{c}34 \% \\
3090-\end{array}$ & 45.9 & $\begin{array}{c}71.4 \\
104.7\end{array}$ & 330 & 290 & $\begin{array}{l}87.1 \\
53.6-\end{array}$ & - \\
\hline & & Min-Max & 16800 & 7900 & 91-291 & 9170 & $125-1661$ & 2890 & $162-7900$ & $88-9860$ & 1490 & - \\
\hline \multirow[t]{2}{*}{$\mathrm{Si}$} & \multirow[t]{2}{*}{9} & Median & 8350 & b. 1 & 8600 & 15300 & bdl & bdl & 15800 & 16050 & 9400 & - \\
\hline & & $\begin{array}{l}2 \sigma \\
\text { Min-Max }\end{array}$ & $\begin{array}{l}2225 \\
4700- \\
35600\end{array}$ & bdl & $\begin{array}{c}3200 \\
5600- \\
39800\end{array}$ & $\begin{array}{c}1620 \\
11900- \\
24200\end{array}$ & bdl & bdl & $\begin{array}{c}1869 \\
12500- \\
25400\end{array}$ & $\begin{array}{c}2125 \\
11600- \\
37400\end{array}$ & $\begin{array}{l}1758 \\
5900- \\
13900\end{array}$ & - \\
\hline \multirow[t]{3}{*}{ K } & \multirow[t]{3}{*}{2} & Median & bdl & 381 & bdl & bdl & 36 & bdl & 75.5 & 68 & 32.5 & - \\
\hline & & $2 \sigma$ & bdl & 26 & bdl & bdl & 18 & bdl & 16.3 & 18.4 & 14.3 & - \\
\hline & & Min-Max & $b d l$ & $381-381$ & $b d l$ & $b d l$ & $36-36$ & $b d l$ & $60-94$ & $28-160$ & $30-61$ & - \\
\hline \multirow[t]{3}{*}{$\mathrm{Ti}$} & \multirow[t]{3}{*}{5} & Median & 46 & bdl & 94.8 & 75.6 & 122 & 78.2 & 109 & 108 & 53.7 & - \\
\hline & & $2 \sigma$ & 9.4 & bdl & 9.8 & 4.9 & 9.5 & 11.8 & 7.4 & 29.7 & $\begin{array}{l}4.6 \\
7.2-\end{array}$ & - \\
\hline & & Min-Max & $0.8-917$ & $b d l$ & 7.4-589 & $63.2-97.1$ & $61.4-226$ & $40.1-226$ & $1.67-537$ & $61.2-1820$ & 164.7 & - \\
\hline
\end{tabular}


Journal Pre-proof

\begin{tabular}{|c|c|c|c|c|c|c|c|c|c|c|c|c|}
\hline \multirow[t]{2}{*}{ V } & 8 & Median & 18.4 & bdl & 66.4 & 12.5 & 95.4 & 94.5 & 67.5 & 130 & 44.5 & 2580 \\
\hline & & $2 \sigma$ & 1.9 & bdl & 5.2 & 1.1 & 6.3 & 7.7 & 4.4 & 15.3 & 3.2 & - \\
\hline \multirow[t]{2}{*}{$\mathrm{Cr}$} & 8 & Median & 974 & 5 & 2705 & 31.6 & 1920 & 9460 & 5.7 & 3510 & 19.1 & 70 \\
\hline & & Min-Max & $3.7-13400$ & $4.1-7.5$ & $41-16770$ & $26.7-33.7$ & $38.6-9620$ & 54300 & $3.3-16.3$ & 84500 & $3.5-1129$ & $16-314$ \\
\hline \multirow[t]{2}{*}{$\mathrm{Mn}$} & 5 & Median & 301 & 227 & 230 & 1077 & 123 & 127 & 194 & 196 & 135 & - \\
\hline & & Min-Max & $235.7-2930$ & 312 & $148.7-678$ & 1174 & 168.3 & $\because J$ & 173-809 & 4700 & 179.3 & - \\
\hline \multirow[t]{3}{*}{ Co } & 5 & Median & 12.3 & 17.4 & 8 & 15.8 & 13. & 14.7 & 12.9 & 13.5 & 20.1 & - \\
\hline & & $2 \sigma$ & 1.86 & 4.02 & 9.27 & 0.79 & 0,6 & $\begin{array}{r}1.75 \\
13.5-\end{array}$ & 0.87 & 1.18 & $\begin{array}{l}1.97 \\
17.2-\end{array}$ & - \\
\hline & & Min-Max & $4.1-48$ & $8.3-72$ & $5.8-70$ & $1 \cdot 1.6-5.3$ & $11.1-130$ & 26.5 & $10.1-16$ & $12-40.5$ & 33.6 & - \\
\hline $\mathrm{Ni}$ & 13 & Median & 47 & 38.5 & 18.8 & 1. 40 & 111 & 97.2 & 74.9 & 181 & 28.7 & 477 \\
\hline \multirow{2}{*}{$\mathrm{Cu}$} & & $2 \sigma$ & 638.4 & $1 ? .19$ & 128 & 151 & 3.70 & 14.4 & 71.7 & 30.5 & 17.2 & - \\
\hline & & Min-Max & $1.7-5920$ & 2920 & $6.9-3500$ & $3.48-370$ & $29.2-29.2$ & $7.8-10$ & $0.94-1080$ & $1.6-70$ & $0.7-163$ & $8-102$ \\
\hline \multirow[t]{3}{*}{$\mathrm{Ga}$} & 4 & Median & 0.32 & bdl & bdl & 0.18 & bdl & bdl & 0.22 & 0.25 & 0.29 & - \\
\hline & & $2 \sigma$ & 0.14 & bdl & bdl & 0.10 & bdl & bdl & 0.13 & 0.12 & 0.14 & - \\
\hline & & Min-Max & $0.22-1.29$ & $b d l$ & $b d l$ & $0.18-0.18$ & $b d l$ & $b d l$ & $0.15-0.34$ & $0.14-0.76$ & $\begin{array}{c}0.19 \\
0.56\end{array}$ & - \\
\hline
\end{tabular}

Values below the limits of detection are not considered. Abbreviations: V=veins, GM=groundmass, bdl=below the detection limits

*Average of the differences measured between the known element content of the international standard BHVO or NIST (for Ni) and the content obtained running the standard as an unkown (relative error). 


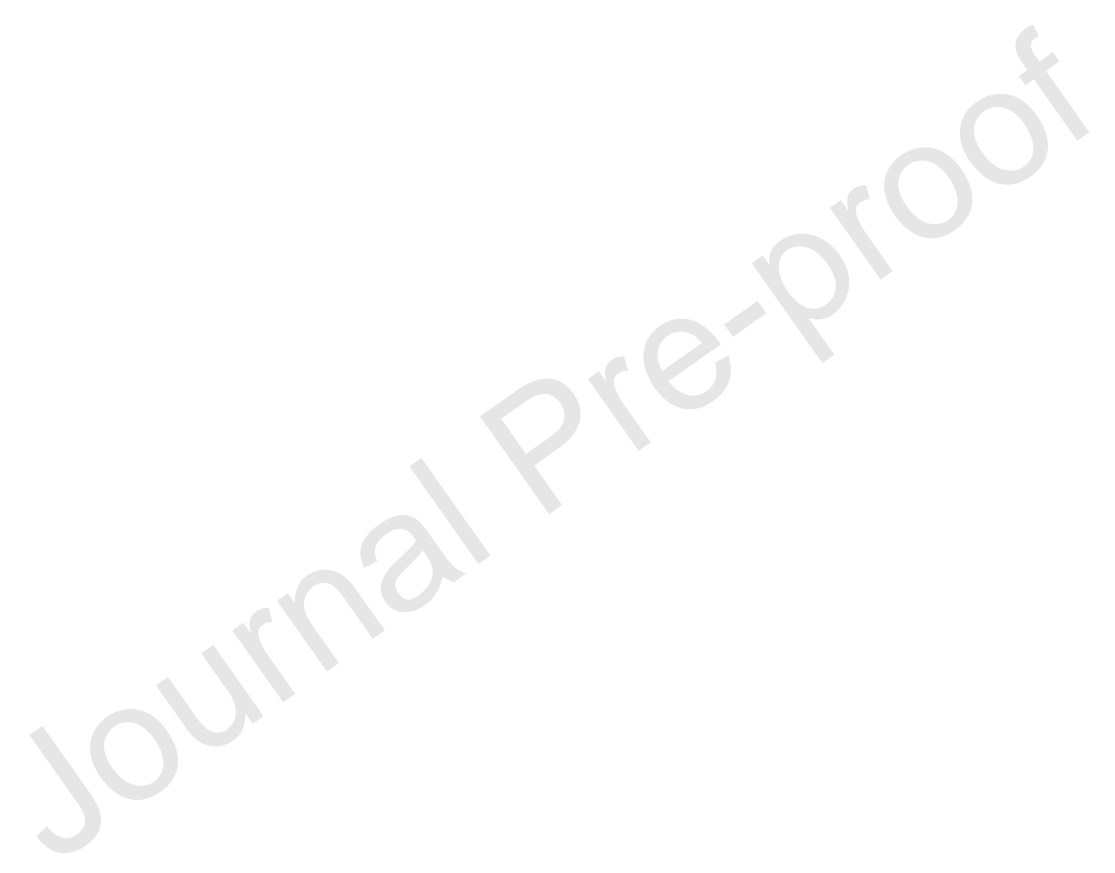




\subsection{Alteration of ultramafic rocks at the MCHS}

Altered and mineralized rocks at the MCHS (figure 3A, B) plot outside the range defined by deeply altered and mineralized serpentinites (i.e. stockwork anu teatite) beneath the SMS at the Rainbow hydrothermal site (Marques et al., 2007). At th Mi 'HS, the barren serpentinite is close to the serpentinite pole (figure $3 \mathrm{~A}$ ) and mimics $\mathrm{t}$ e s s Jुnature of present-day oceanic serpentinites (Marques et al., 2007; Andreani et al., 2014).

Where mineralization occurs in a stockwork structure replacing serpentinites at the Rainbow hydrothermal site, the $\mathrm{Fe}_{2} \mathrm{O}_{3}$ and $\mathrm{SiO}_{2}$ con 1 's of the rocks increase and decrease, respectively. This reflects the formation $f$ re-rich sulfides and magnetite replacing serpentinite (Marques et al., 2007). Seaí. no' altered serpentinites are locally characterized by extensive steatisation (Marques et $a^{\prime}, 200 \%$ ) resulting in their proximity to the talc pole (figure 3A) and the increase of their $\mathbf{3 1}$ ح content (figure 3B), which is not observed in altered rocks at the MCHS. Rather, a Fe- a ricn metasomatism occurred leading to an increase of the $\mathrm{Fe}_{2} \mathrm{O}_{3}$ content of the rocks tos the with a decrease of the $\mathrm{SiO}_{2}-\mathrm{CaO}$ content, consistently with the replacement of serent ${ }_{1}$ ites by Fe-Ca-rich silicates. This explains the position of the Fe-Ca-silicates in betwe $\mathrm{n}$ th $\geqslant$ ilvaite and serpentinite poles. The sample Cot18_46 displays a higher degree of replace, nent consistently with its closest position to the ilvaite pole. The semimassive sulfides are shifted towards the magnetite pole accordingly to the presence of magnetite replacing serpentine in these facies. As a consequence, the $\mathrm{Fe}_{2} \mathrm{O}_{3}$ content increases and the $\mathrm{SiO}_{2}$ content slightly decreases in these samples. Noticeably, the $\mathrm{Fe}_{2} \mathrm{O}_{3}$ content in the altered and mineralized rocks at the MCHS is higher than the one reported in deeply mineralized rocks beneath the Rainbow hydrothermal system.

The carbonated samples from Snake Pit display quite homogenous chemical signatures shifted towards the calcite pole. This leads to an apparent decrease of the $\mathrm{SiO}_{2}-\mathrm{CaO}$ content without significant enrichment in $\mathrm{Fe}_{2} \mathrm{O}_{3}$. This carbonation resulted from a low-T (of about $130^{\circ} \mathrm{C}$ ), seawater-derived hydrothermal stage which represents the latest oceanic hydrothermal stage 
recorded at the MCHS (Coltat et al., 2019b). The potential remobilization of the former metal stock during this event is discussed below.

At the MCHS, Fe-Ca-rich metasomatism and mineralization formation are accompanied by an increase of the $\mathrm{Co} / \mathrm{Ni}$ ratio (figure 3C, D). A similar evolution is noticed in the deeply altered and mineralized rocks from the Rainbow hydrothermal site. This peculiarity is less clear in the mineralized rocks from Snake Pit. The high $\mathrm{Cu}$ and $\mathrm{Zn}$ content increase in mineralized rocks from the MCHS are comparable to the ones reported in deeply mineralized and altered rocks from the Rainbow hydrothermal site. There is no apparent relationship between the $\mathrm{Co} / \mathrm{Ni}$ ratio and the metal content.
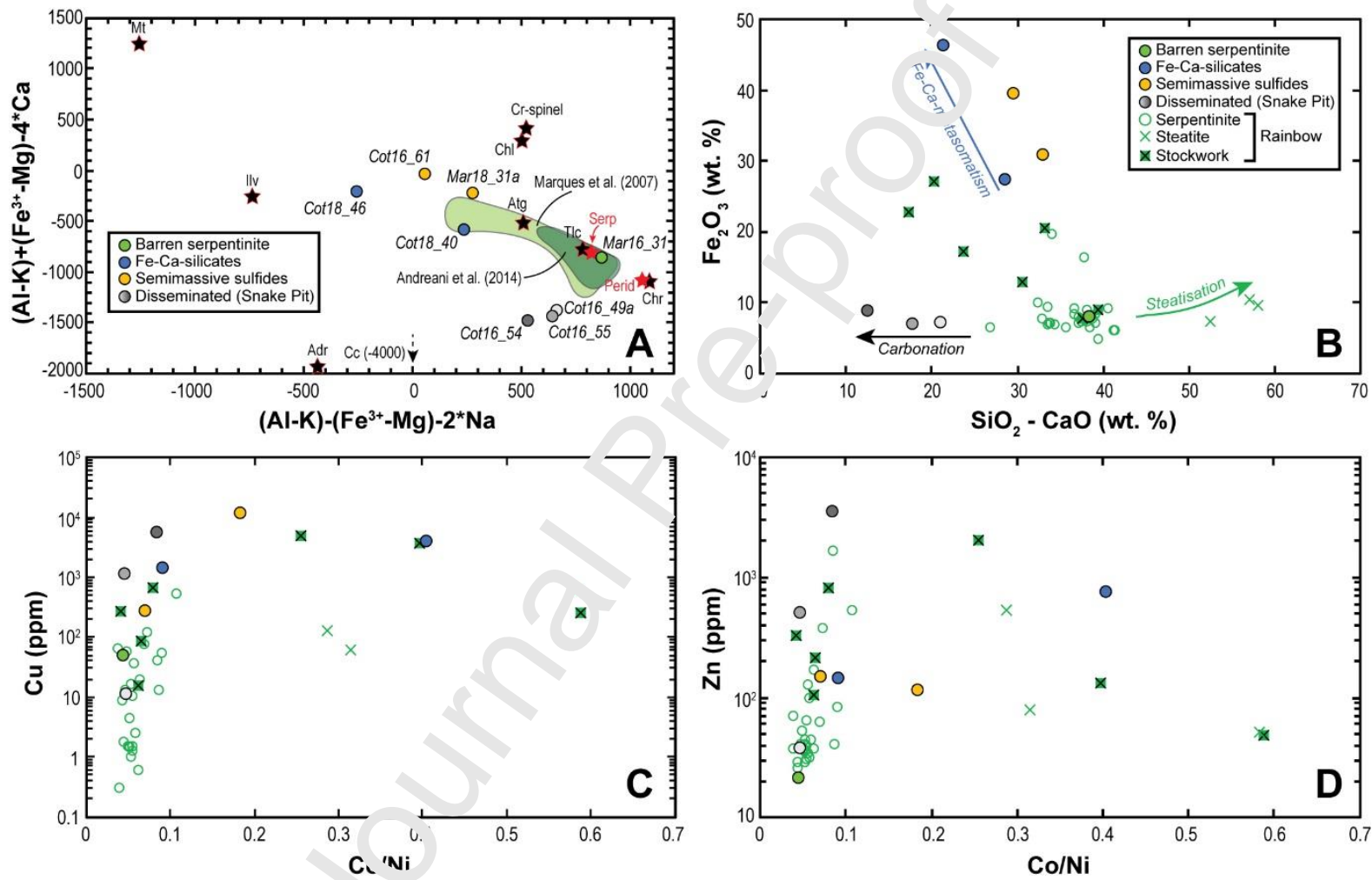

Figure 3. Chemico-minor ilogical discriminant diagram (A, after de La Roche and Marchal, 1978), major (B) and trace (C, D) element compositions of the barren, altered and mineralized rocks at the MCHS compared to present-day equivalents (from Marques et al., 2007; Andreani et al., 2014). Mt=magnetite, Atg=antigorite, Ilv=ilvaite, Adr=andradite, $C c=$ calcite, Chl=chlorite, Tlc $=$ talc, Chr=chrysotile, Serp=serpentinite, Perid $=$ peridotite.

The Cu-rich Massive Sulfides at the MCHS present geochemical signatures similar to the ones of seafloor massive sulfides (table 2) allowing to compare their relative metal enrichments (figure 4). Ultramafic-hosted mineralized systems are characterized by $\mathrm{Fe}$ content lower than the one of mafic-hosted mineralization (figure 4). The $\mathrm{Cu}$-rich MS at the 
MCHS are between mafic or ultramafic signatures but display a tendency toward high Co content. This is consistent with the mineralization being hosted in ultramafic rocks

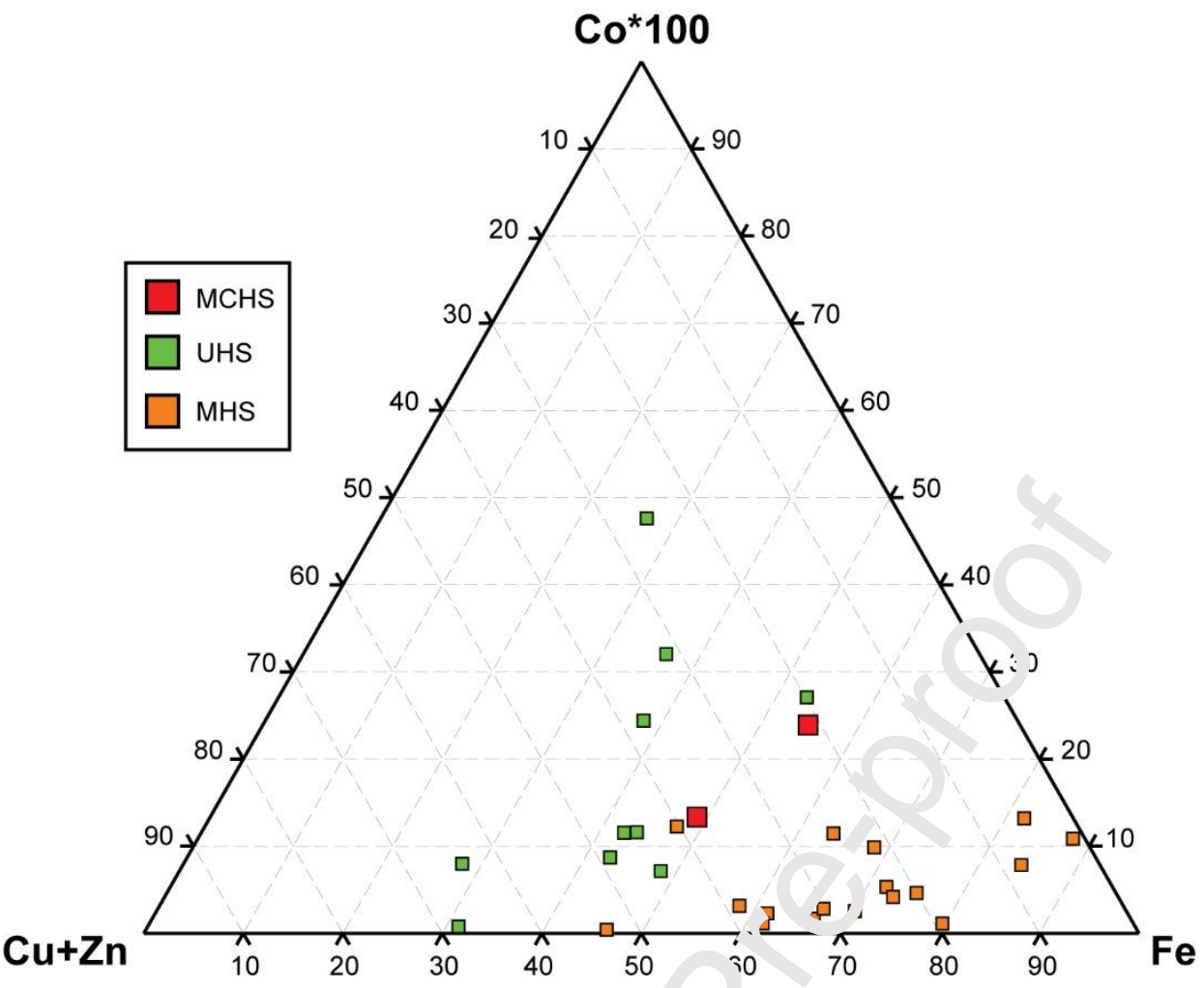

Figure 4. Ternary diagram of normalizea . netal composition of the Cu-rich Massive Sulfides facies at the MCHS compared to preser.-day Seafloor Massive Sulfides (from Fouquet et al., 2010).

\subsection{Vertical distribution of len.ents}

\subsubsection{Whole rock}




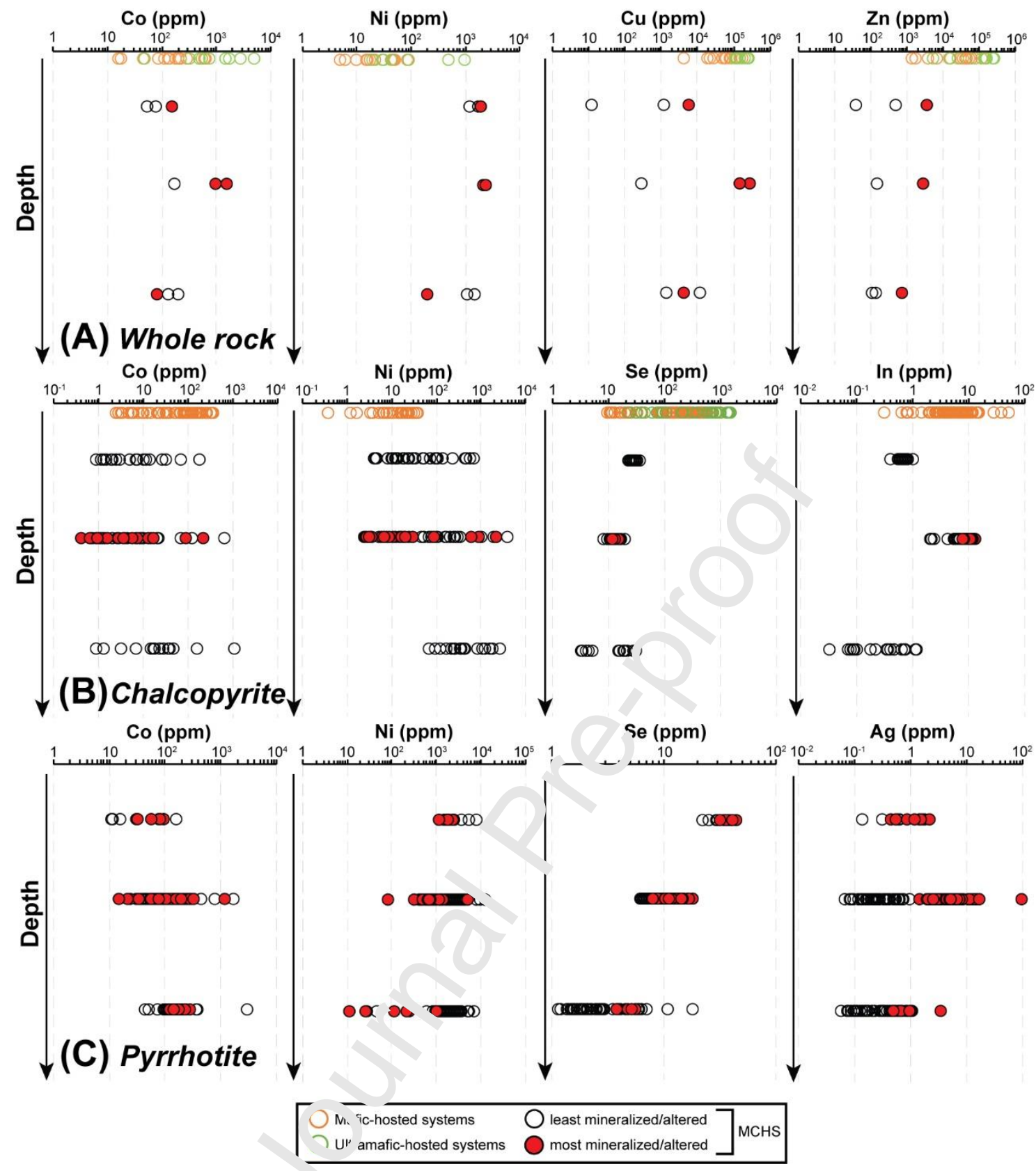

Figure 5. Vertical distr: h'tion of selected trace (A) elements in whole rocks and trace element in chalcopyrite $(B)$ and pyrrhotite $(C)$. At a given depth, the most mineralized/altered samples are displayed in red. All distributions are compared to values of present-day seafloor massive sulfides at mafic- and ultramafic-hosted systems (when available in the literature). (from Fouquet et al., 2010 and references therein; Wohlgemuth-Ueberwasser et al., 2015; Melekestseva et al., 2017; Grant et al., 2018; Yuan et al., 2018)

Whole rock compositions are marked by an increase of the $\mathrm{CaO}$ together with the $\mathrm{Sr}$ content (table 1) at Snake Pit, likely in relation to carbonation. $\mathrm{MgO}$ and $\mathrm{MnO}$ are also enriched there, 
whereas $\mathrm{Fe}_{2} \mathrm{O}_{3}$ is depleted. Trace elements (figure 5A) do not display specific evolution upwards.

Noticeably, the Ni content of mineralized rocks at the MCHS is higher than the one of present-day SMS either in mafic- or ultramafic-hosted systems, whereas the Co contents are comparable (Fouquet et al., 2010). As a consequence, the $\mathrm{Co} / \mathrm{Ni}$ ratio of whole rocks at the MCHS is lower than the one of present-day massive sulfides (figure 6), the lowest values being recorded at Snake Pit. At a given structural level, the highest $\mathrm{Co} / \mathrm{Ni}$ ratio is recorded in the most altered and/or mineralized samples (figure 6). It seems that this ratio decreases upwards at the MCHS (figure 6). $\mathrm{Zn}$ is depleted at the MCHS compared to present-day systems. Finally, the highest $\mathrm{Cu}$ contents of the MCHS are recoic ' $\mathrm{d}$ at Marmorera section and are comparable to present-day seafloor massive sulfides.

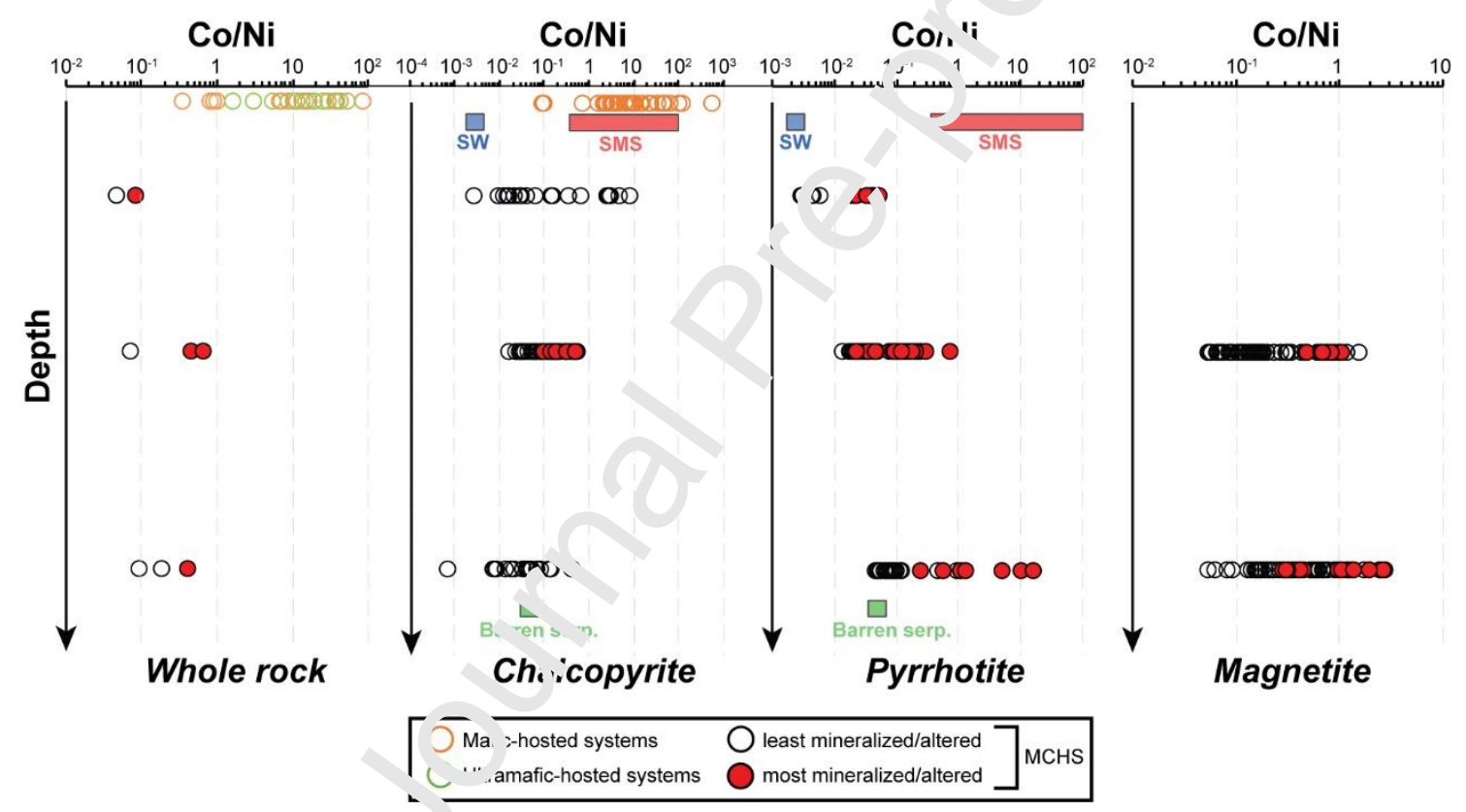

Figure 6. Co/Ni ratio o, whole rocks and metal-bearing phases (chalcopyrite, pyrrhotite and magnetite) from the MCHS compared to present-day Seafloor Massive Sulfides and chalcopyrite (there is no LA-ICPMS data in the literature for pyrrhotite and magnetite). At a given depth, the most mineralized/altered samples are displayed in red. The Co/Ni ratio of barren serpentinites (Barren serp., green square), seawater (SW, blue square) and seafloor massive sulfides (SMS, red boxes) are plotted. The Co/Ni ratio of barren serpentinites ( 0.05) is averaged from chemical compositions of worldwide serpentinites in the literature consistently with the one measured in the barren serpentinite analyzed in this study. The Co/Ni ratio for seawater is from Sohrin et al. (1998). Note that the two lowest Co/Ni ratios measured in present-day chalcopyrite are the ones of minerals from the stockwork beneath 
the TAG hydrothermal mound. Whole rocks and single grain chemical data from Fouquet et al., 2010 and references therein; Melekestseva et al., 2017; Grant et al., 2018; Yuan et al., 2018 .

\subsubsection{Minerals}

\subsubsection{Chalcopyrite}

In chalcopyrite, $\mathrm{Ni}$ and $\mathrm{Te}$ concentrations decrease upwards (Te is below the limits of detection at Snake Pit) and Se concentrations increase (figure 5B). Chalcopyrite from SMS extends these trends for $\mathrm{Ni}$ and Se displaying low $\mathrm{Ni}$ and high Se concentrations $\left(10^{-1}\right.$ to $10^{2}$ ppm and $10^{1}$ to $10^{3} \mathrm{ppm}$, respectively). On the other hand, $c_{1}$ ?lcopyrite from present-day SMS displays Te contents one to two orders of magnitude igh r than those of the MCHS (table 3). Indium does not display particular vertica di tribution, with maximum In concentration at Marmorera (up to $13 \mathrm{ppm}$ ) being comna able to present-day systems (figure 5B). Cobalt concentrations overlap along the sectio. (f gure $5 \mathrm{~B}$ ). The $\mathrm{Co} / \mathrm{Ni}$ ratio spans a wide range, especially at Snake Pit (from $10^{-3} \sim 10^{1}$, figure 6) and describes a funnel-like evolution. At Cotschen, the $\mathrm{Co} / \mathrm{Ni}$ ratio is lose to the one of barren serpentinite $(0.05)$ whereas at Snake Pit the $\mathrm{Co} / \mathrm{Ni}$ ratio $\mathrm{dr}$ as between the ones of seawater $(0.0025)$ and chalcopyrite from SMS ( from $1 \mathrm{C}^{0}$ to $16^{3}$ ). At Marmorera, the highest $\mathrm{Co} / \mathrm{Ni}$ ratio is measured in the most mineralized sa $\mathrm{n}: \sim$ (1.e. in the $\mathrm{Cu}$-rich massive sulfides facies).

\subsubsection{Pyrrhotite}

In pyrrhotite (figure 5C), t'e $S_{1}$, content increases upwards similarly to chalcopyrite (figure 5B), from 1 to $18 \mathrm{ppm}$ a Co schen to 22 to $44 \mathrm{ppm}$ at Snake Pit. A slight increase of the Ge content occurs upwards ( rble 4). The maximum of the Ag content is recorded in $\mathrm{Cu}$-rich $\mathrm{MS}$ from Marmorera (up to $97 \mathrm{ppm}$ ).

Nickel concentrations increase upwards (from $10^{1}$ to $10^{4} \mathrm{ppm}$ at Cotschen to $10^{3}$ to $10^{4} \mathrm{ppm}$ at Snake Pit) whereas Co decreases upwards. As a result, the $\mathrm{Co} / \mathrm{Ni}$ ratio decreases regularly upwards and get close to the value of seawater (figure 6). Realistically, the $\mathrm{Co} / \mathrm{Ni}$ ratio in pyrrhotite is between the ones of seawater, barren serpentinites and present-day seafloor massive sulfides (figure 6). The highest $\mathrm{Co} / \mathrm{Ni}$ ratios are measured in the most mineralized/altered samples at a given depth similarly to what is measured in chalcopyrite (figure 6).

\subsubsection{Magnetite}


Magnetite has been only observed at Cotschen and Marmorera (figure 2C). A slight increase of $\mathrm{Co}, \mathrm{Ni}, \mathrm{V}$ and $\mathrm{Ti}$ concentrations is documented upwards (table 5). Mn concentrations are identical for the two sites. A large dispersion of trace elements in magnetite is the most prominent feature (table 5), likely in relation with the different textural forms of magnetite identified from petrography (i.e. in veins or in the groundmass around spinel relics, figure $2 \mathrm{C}$ ). Noticeably, the $\mathrm{Co} / \mathrm{Ni}$ ratio of magnetite is highest in the most mineralized/altered facies both at Cotschen and Marmorera (figure 6), as it was documented for chalcopyrite and pyrrhotite.

\subsection{Lateral distribution of elements at Marmorera}

\subsubsection{Whole rock}

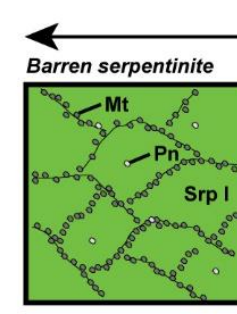

Distance to mafic dyke
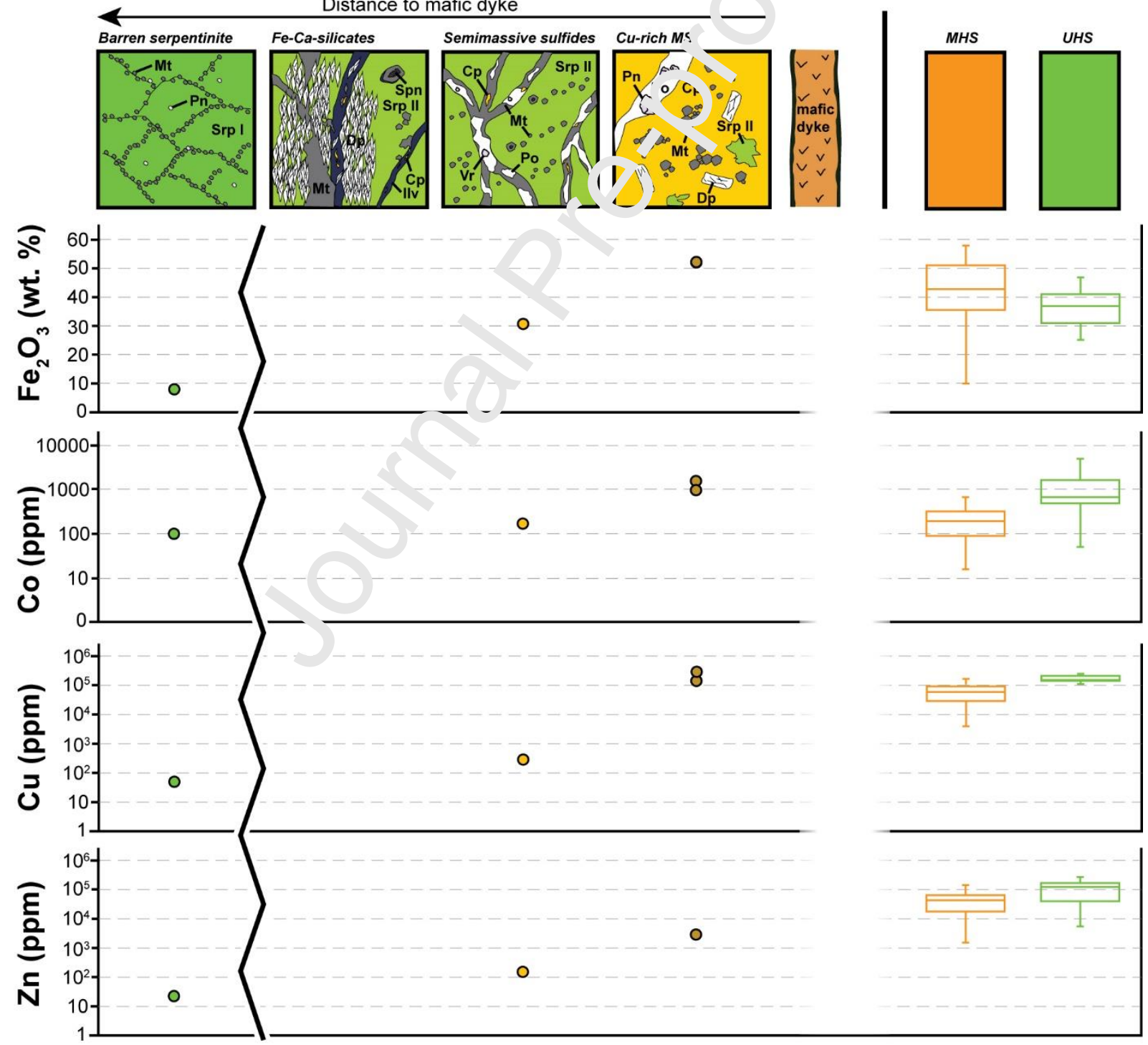

Figure 7. Major and trace element compositions of whole rocks of the Marmorera mineralized system. Data from present-day seafloor massive sulfides are reported as box 
plots for comparison (from Fouquet et al., 2010 and references therein). The boxplot is built as follow, in this figure and in the following, from the bottom to the top: minimum, first quartile, median, third quartile, maximum values. MHS=Volcanic-Hosted Systems, UHS=Ultramafic-Hosted Systems.

Major and trace element of Marmorera samples are displayed in figure 7. Towards the mafic dyke, the $\mathrm{Fe}_{2} \mathrm{O}_{3}$ content increases whereas the $\mathrm{SiO}_{2}$ and $\mathrm{MgO}$ contents decrease (tables 1, 2). These evolutions are consistent with the replacement of former serpentine by metal-bearing phases (figure $2 \mathrm{C}$ ). $\mathrm{CaO}$ is slightly enriched in one sample of the $\mathrm{Cu}$-rich $\mathrm{MS}$ facies where it is hosted by metasomatic diopside.

Progressive enrichments of $\mathrm{Co}, \mathrm{Cu}$ and $\mathrm{Zn}$ are recorded towa ${ }^{-1 s} 1$ le mafic dyke (figure 7). In the $\mathrm{Cu}$-rich MS facies, the $\mathrm{Co}$ and $\mathrm{Cu}$ contents are clos to hose measured in present-day seafloor massive sulfides, whereas the $\mathrm{Zn}$ content is nnc to two orders of magnitude lower. The Ni concentrations are roughly constant at Marme ${ }^{\text {er }} \mathrm{d}(\sim 2200 \mathrm{ppm})$ and are one to three orders of magnitude higher than in present-day st afloor massive sulfides (tables 1,2$)$ ). The $\mathrm{Co} / \mathrm{Ni}$ ratio of the whole rocks (figure 8) dis ${ }_{\mathrm{r}}^{-1}$ ays a well-defined increase towards the mafic dyke, where it reaches values comparab! to the lowest ones measured at present-day seafloor massive sulfides. 

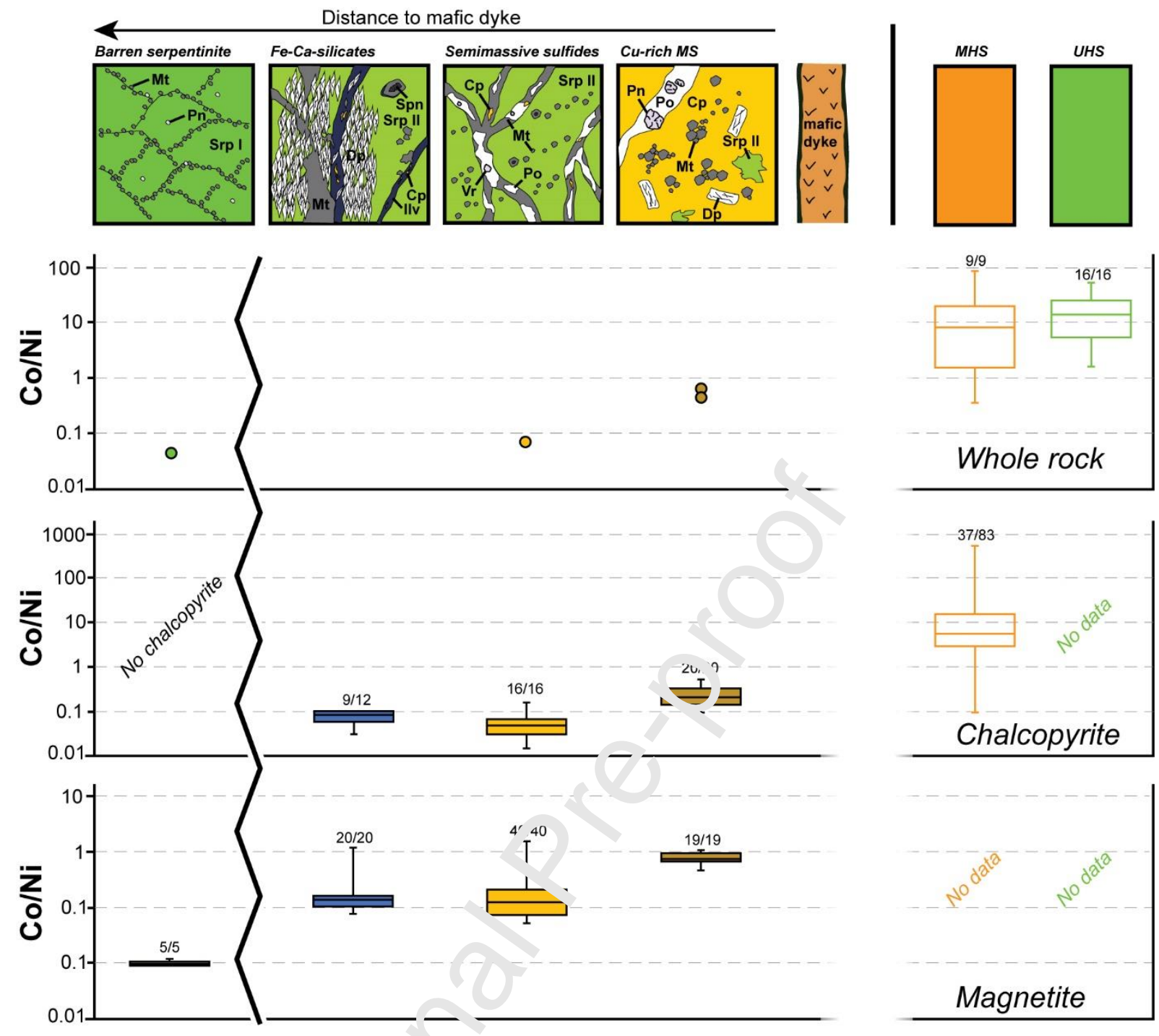

Figure 8. Co/Ni ratio variation in varren serpentinites, mineralized facies and hydrothermal phases of the Marmorera $w^{\text {inerc }}$ ized system. SMS and chalcopyrite from present-day systems are displayed for compa isor. (from Fouquet et al., 2010 and references therein; Melekestseva et al., 2017; Grant et al., 2018; Yuan et al., 2018). No LA-ICPMS Co contents available for magnetite. The ratio displayed above the boxplots indicates the number of values above the limits of detection against the number of analyses.

\subsubsection{Minerals}

\subsubsection{Chalcopyrite}



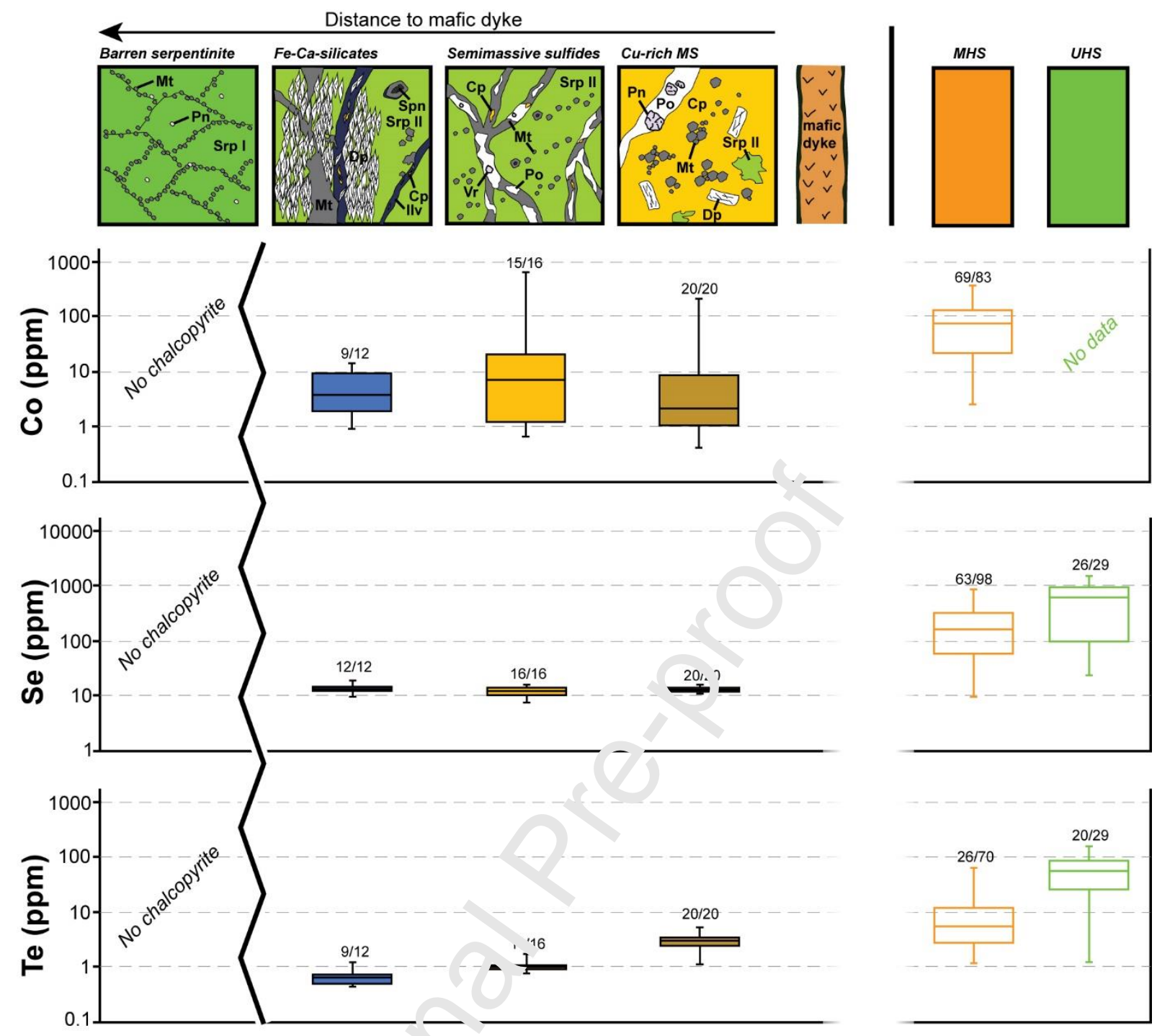

Figure 9. Concentrations of elected trace elements in chalcopyrite of the Marmorera mineralized system. Chalc. nyri e from present-day hydrothermal systems are reported for comparison (data from Wor'gemuth-Ueberwasser et al., 2015; Melekestseva et al., 2017; Grant et al., 2018; Yuan $\epsilon^{*}$ al., 2018).

In chalcopyrite (figure 9), the Co content is variable along the section without clear evolution towards the mafic dyke. The same evolution is recorded for the Ni content (table 3). The Ni content in the $\mathrm{Cu}$-rich MS facies is close to the one of present-day systems, whereas the Co content is one to two orders of magnitude lower than present-day systems (table3, figure 9). The Ni content appears slightly lower in the $\mathrm{Cu}$-rich MS facies compared to other hydrothermal facies (table 3). At first sight, the $\mathrm{Co} / \mathrm{Ni}$ ratio of chalcopyrite slightly increases towards the mafic dyke reaching values comparable to the lower ones of chalcopyrite from present-day systems (figure 8). 
The Se content is constant along the profile. In present-day systems, Se content of chalcopyrite is one to two orders of magnitude higher than at Marmorera (figure 9). The Te content increases progressively towards the mafic dyke.

\subsubsection{Pyrrhotite}

In pyrrhotite $\mathrm{Co}$ is slightly enriched in the $\mathrm{Cu}$-rich MS facies compared to the semimassive sulfides facies, whereas Ni strongly decreases (table 4). This leaves a $\mathrm{Co} / \mathrm{Ni}$ ratio which increases towards the mafic dyke (figure 8).

Selenium slightly increases towards the mafic dyke, wherea Ge slightly decreases. Finally, Ag strongly increases in $\mathrm{Cu}$-rich MS compared to semima sivt sulfides with a median around 0.24 and 5 , respectively.

\subsubsection{Magnetite}




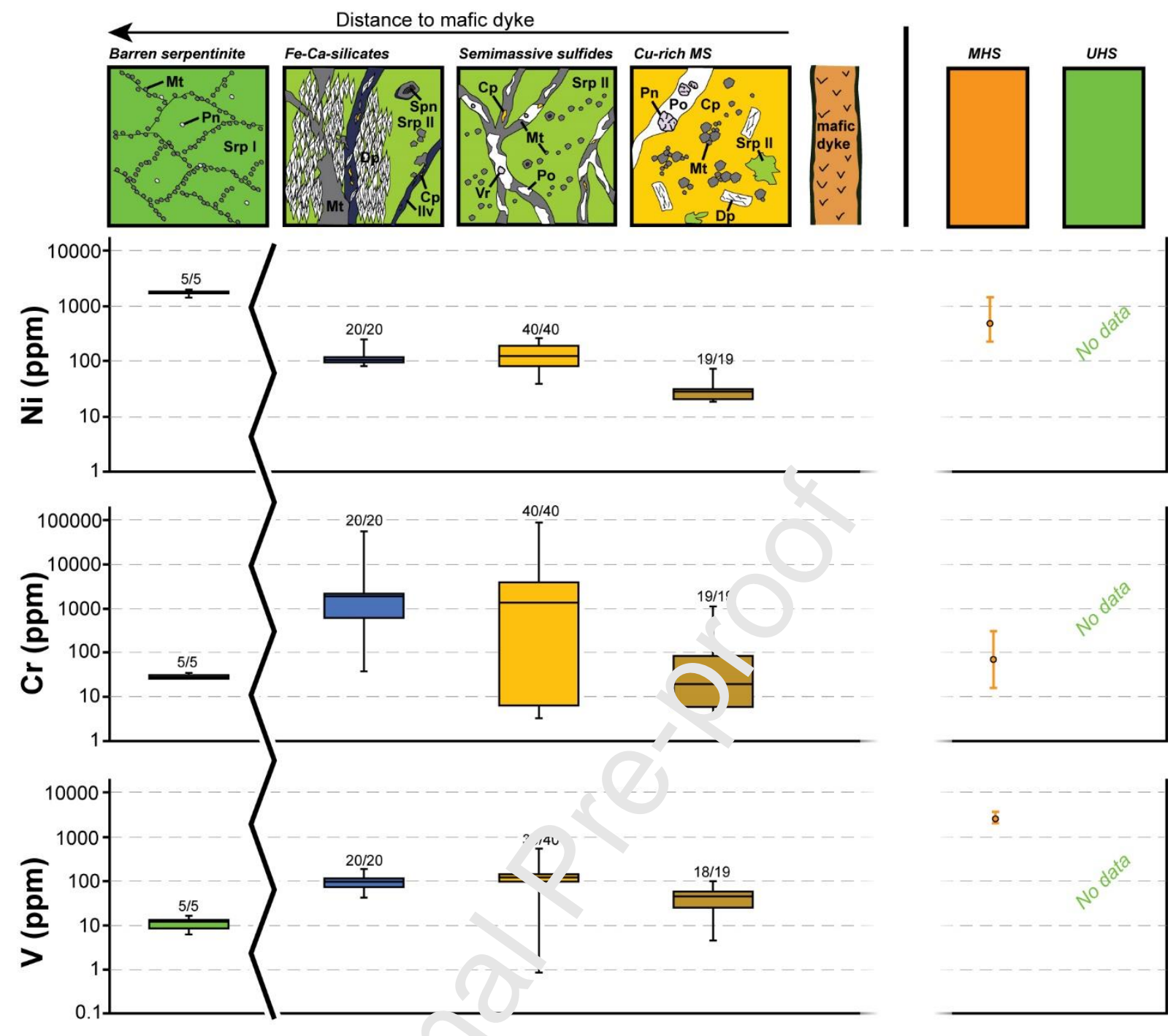

Figure 10. Concentrations o, s'ected trace elements in magnetite of the Marmorera mineralized system. Magnetite . ${ }_{\text {rum }}$ present-day systems are reported for comparison (data from Patten et al., 2016)

In magnetite (figure 1 ), $\mathrm{Ni}$ decreases towards the mafic dyke as it was observed for pyrrhotite and to a lesse 1 extent for chalcopyrite (figure 9). The Co content is rather constant along the profile even if a slight increase may be noticed in the $\mathrm{Cu}$-rich MS facies (table 5). As a consequence, the $\mathrm{Co} / \mathrm{Ni}$ ratio increases in magnetite towards the mafic dyke (figure 8). $\mathrm{V}, \mathrm{Cr}$ and $\mathrm{Ti}$ do not display a clear evolution towards the mafic dyke (table 5, figure 10). Barren serpentinites display somewhat lower $\mathrm{V}$ contents than their mineralized equivalents. Also, the semi-massive sulfides are characterized by a large dispersion of contents in $\mathrm{Cr}, \mathrm{V}$ and $\mathrm{Ti}$ (table 5, figure 10).

In figure 11, we describe in more details the composition of magnetite, in relation with its textural position in the semimassive sulfides facies. 

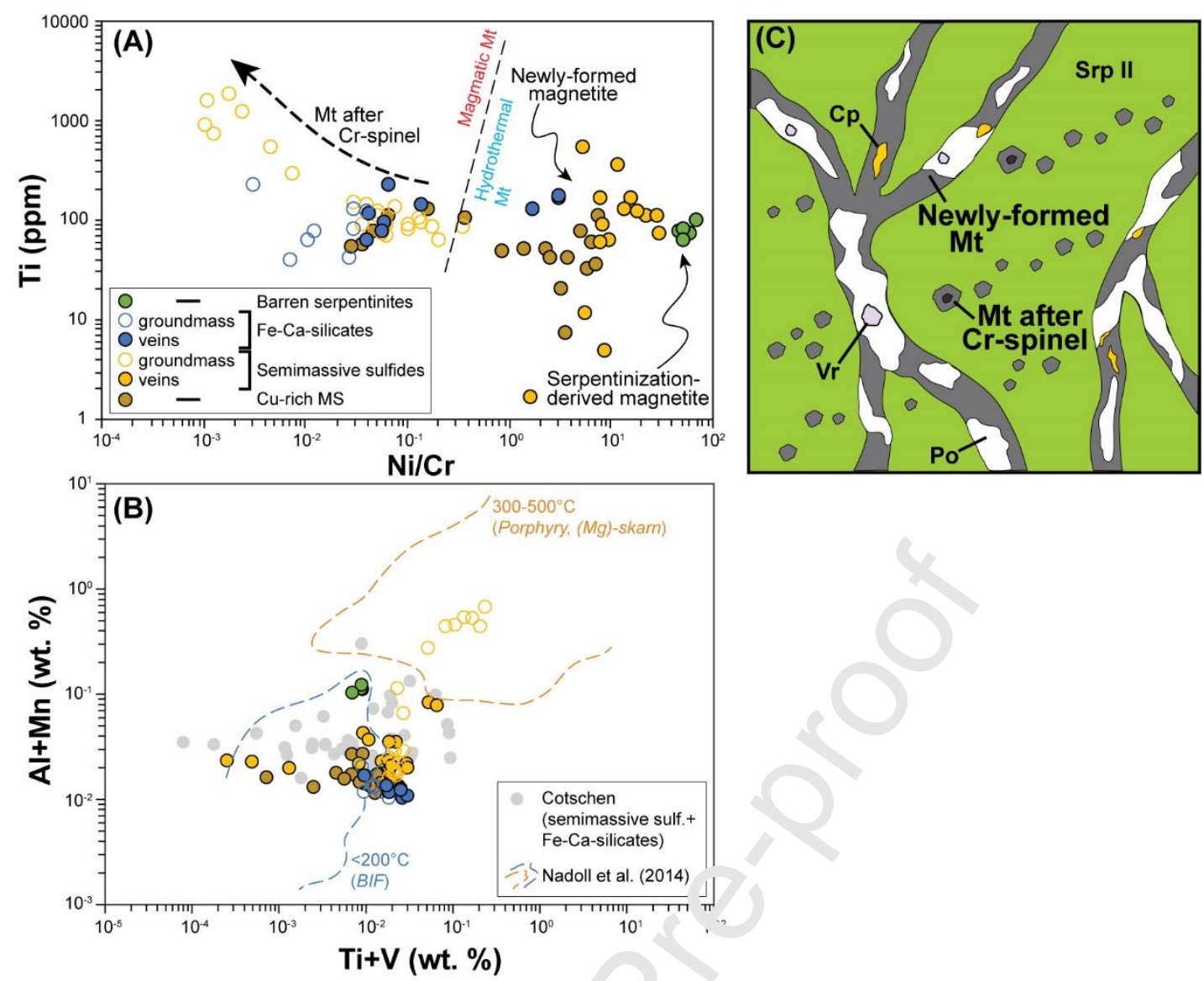

Figure 11. (A) Ti vs. Ni/Cr discriminant a. 'gram of trace element compositions of magnetite from the Marmorera mineralized syste.' (from Dare et al., 2014). Note that the field defined for magmatic and hydrothermal magr et 1 e is displayed although it is rather discriminant for higher Ti concentrations. (B) $1+1+\operatorname{lin}$ vs. Ti+V discriminant diagram of trace element compositions of magnetite f $\mathrm{w}$. the Marmorera and Cotschen mineralized system (from Nadoll et al., 2014). (C) Scr?n e of the semimassive sulfides facies at Marmorera in which magnetite occurs e.'he, a ound former spinel or together with pyrrhotite in veins. Mt=magnetite, $C p=$ cholc , pyrite, $P o=$ pyrrhotite, $V r=$ violarite, SrpII=serpentine.

Magnetite in barren serpentinites displays the highest Ni/Cr ratio of about 60. Magnetite of the Fe-Ca-silicates and semimassive sulfides facies can be either found in the groundmass or in veins (figure 11C). In general, magnetite in the groundmass displays higher Ti content and lower $\mathrm{Ni} / \mathrm{Cr}$ ratio than the one of veins (figure 11A). This is especially clear for magnetite of the semimassive sulfides facies. In the $\mathrm{Cu}$-rich MS facies, magnetite displays variable $\mathrm{Ti}$ contents and $\mathrm{Ni} / \mathrm{Cr}$ ratios overlapping those of semimassive sulfides and Fe-Ca-silicates facies. Unfortunately, the petrographic analysis did not allow to specify the textural features of magnetite in the $\mathrm{Cu}$-rich MS facies. 
In figure $11 \mathrm{~B}$, magnetite from the MCHS are widespread, covering both the field of low-T magnetite (from BIF deposits, Nadoll et al., 2014) and high-T magnetite (from porphyry and skarns deposits, Nadoll et al., 2014). A clear relationship between a hydrothermal facies and a given formation temperature is ambiguous. Rather, geochemical signatures of magnetite in the semimassive sulfide plot both in the low-T and high-T fields (figure 11B) precluding a straightforward of these signatures.

\subsection{Carbonated rocks at Snake Pit}

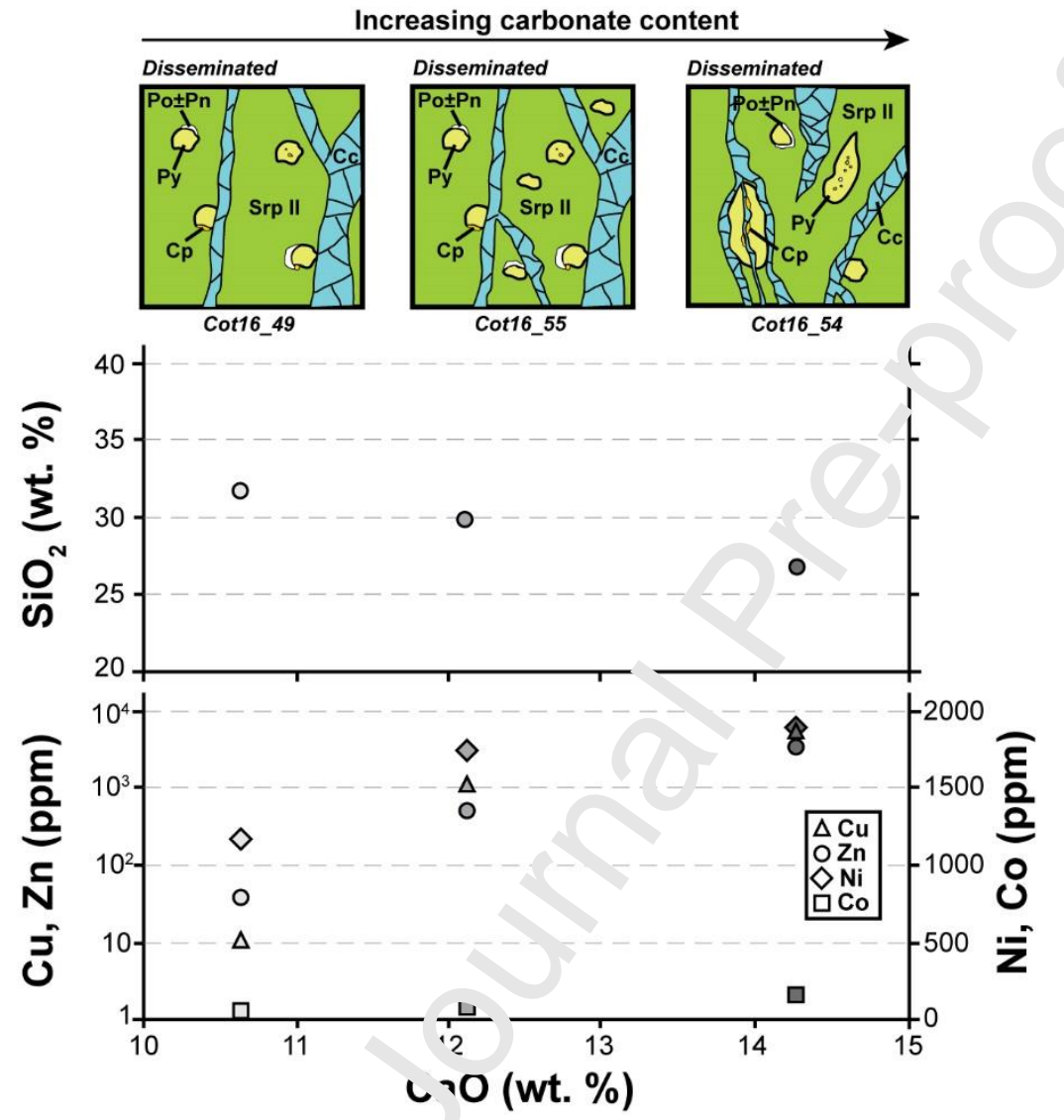

Figure 12. Concentrations of selected major and trace element in ophicalcites displaying variable degree of carbonation at Snake Pit.

At Snake Pit, the mineralized serpentinites are variably carbonated (figure 12 ). The $\mathrm{CaO}$ content is consistently variable (between 10.6 and 14.3 wt. \%). The $\mathrm{SiO}_{2}$ content (from 31.7 to 26.8 wt. \%) is anticorrelated with $\mathrm{CaO}$.

Copper and zinc increase by two orders of magnitude with $\mathrm{CaO}$. This is consistent with the higher content of chalcopyrite and sphalerite in this sample. Cobalt and nickel slightly increase. 


\section{Discussion}

\subsection{A hydrothermal origin for the MCHS}

Mineralization associated with ultramafic rocks are ascribed either to hydrothermal processes (similar to present-day ultramafic-hosted black smokers) or to magmatic activity (e.g. orthomagmatic Ti-V-rich oxides deposits and $\mathrm{Cu}-\mathrm{Ni}$-rich sulfides linked to mafic or ultramafic intrusions). Here we have several petrographic and geochemical evidences which show that the mineralization formed in hydrothermal conditions.

The replacement of the serpentinite by the metal-bearing phases is a textural feature arguing for a hydrothermal origin for the mineralization. Coltat et al. (2019b) reported that the former lizardite is replaced by Fe-antigorite/greenalite where the minera: ${ }^{\prime}$ zation occurs suggesting a metasomatic transformation during the fluid circulation.

Additionally, in magnetite, the low Ti contents coupled to ruit high $\mathrm{Ni} / \mathrm{Cr}$ (figure 11A) agree with a hydrothermal source rather than a magmatic (Tare et al., 2014). The low $\mathrm{Ni} / \mathrm{Cr}$ measured in magnetite in the groundmass are likely iue to their presence around former spinel grains (figure 11B), the latter may co ta $\mathrm{s}$ high $\mathrm{Cr}$ and $\mathrm{Ti}$ contents. Dissolutionreprecipitation processes have likely enrinht.' the newly formed magnetite in $\mathrm{Ti}$ and $\mathrm{Cr}$, lowering the $\mathrm{Ni} / \mathrm{Cr}$ ratio.

At the MCHS, the mineralization is capleted in Pt (it was only detected in few pyrrhotite, $\sim 10 \%$, appendix 2), an element cha ar « -istic of ortho-magmatic mineralized systems within mafic or ultramafic intrusions (' on with a hydrothermal origin for 1 e mineralization.

\subsection{Geochemical recorc's of the variable Fluid/Rock ratio: the profile of Marmorera}

The profile of Marmorera allows discussing the evolution of the Fluid/Rock (F/R) ratio during hydrothermal alteration, mainly for two reasons. First, the mineralization is geometrically controlled, here, by a mafic dyke. Secondly, the mineralization found here (figure 2B) displays the various end-members as a function of the intensity of the hydrothermal alteration at the MCHS (from the barren serpentinites to the $\mathrm{Cu}$-rich MS).

At first order, the rocks close to the mafic dyke are more mineralized than those away from the mafic dyke suggesting that the F/R ratio increased towards the mafic dyke. This increase of the $\mathrm{F} / \mathrm{R}$ ratio likely occurred during a single hydrothermal event, being free of any refining process. Indeed, there is no textural evidence of a previous mineralized assemblage preserved in the $\mathrm{Cu}$-rich MS facies for example. 
During the hydrothermal alteration, a decrease of the $\mathrm{SiO}_{2}$ and $\mathrm{MgO}$ content of the rocks and a gain of metals $(\mathrm{Cu}, \mathrm{Fe}, \mathrm{Co}, \mathrm{Zn})$ are observed. The metal content in the $\mathrm{Cu}$-rich $\mathrm{MS}$ facies is comparable to the one reported at present-day SMS (figures 5, 6, 8, table 2) where the F/R ratio is obviously high. Noteworthy is that the Ni content remains fairly constant, so that the $\mathrm{Co} / \mathrm{Ni}$ ratio of the mineralization was increased towards the dyke. Such an increase of the $\mathrm{Co} / \mathrm{Ni}$ ratio together with the intensity of hydrothermal alteration has been previously reported in UHS (Marques et al., 2006; Fouquet et al., 2010) and in fossil VMS (Toffolo et al., 2017; Coltat et al., 2019b). The low Co/Ni ratios reported at the MCHS $(<1)$ are similar to the ones of deeply mineralized/altered rocks below ultramafic-hosted hyc-othermal systems (Marques et al., 2007). This is consistent with the progressive 1 ?pla ement of serpentinite by hydrothermal phases rather than direct precipitation from the iydrothermal fluid (Fouquet et al., 2010). As a whole, the geochemical variations alo: o the Marmorera profile are thus consistent with an increase of the F/R ratio towards we dyke, from of about 0 in the barren serpentinites to high values in the $\mathrm{Cu}$-rich MS $f_{a c}$ as where fluids likely buffer the chemical composition of the mineralization. By exten on, we propose that the internal geochemical variability observed at the two other i, verigated depths (Cotschen and Snake Pit) of the MCHS may be also explained by va: ${ }^{i}$ able $\mathrm{F} / \mathrm{R}$ ratios. Indeed, the most mineralized samples (red dots in figures 5 and 6) genera' $1 \mathrm{y}$. isplay the highest metal content and $\mathrm{Co} / \mathrm{Ni}$ ratio and the lowest $\mathrm{SiO}_{2}$ and $\mathrm{MgO}$ contents.

\subsection{Vertical evolution of chem co-physical parameters of the F-R interactions.}

The whole range of som $\geqslant$ ge ichemical markers along the vertical section plots out the range measured at Marmorera ( he site where F/R ratios are the largest). These are for example the Se content and the $\mathrm{Co} / \mathrm{Ni}$ ratio. The Se content increases both in pyrrhotite and chalcopyrite upwards precluding a potential partitioning solely explained by a coefficient partition between the two sulfides. To explain the apparent upwards increase of the Se content and the lowering of the $\mathrm{Co} / \mathrm{Ni}$ ratio we have thus to invoke chemico-physical parameters of fluid-rock interactions other than $\mathrm{F} / \mathrm{R}$ ratio variations, that evolved along the vertical section. Like in present-day oceanic hydrothermal systems below black smokers, one may expect variations of pressure, temperature, $\mathrm{pH}$ and changes of $f_{\mathrm{O} 2}$ and $f_{\mathrm{S} 2}$.

Pressure. At the MCHS, the lithostatic pressure decreased from the bottom of the system towards Snake Pit simply because Snake Pt is closer to the detachment (and to the paleo- 
seafloor) than Cotschen. The decrease of the pressure has no strong influence on the solubility of hydrothermal phases (Reed and Palandri, 2006). In addition, mineralogical assemblages reported at present-day UHS and MHS are comparable to those at the MCHS suggesting pressure had no strong control on the mineralogy (even if one considers a slightly different water column depth). Therefore, the pressure decrease is unlikely to explain the variation of the geochemical markers upwards.

Temperature. The temperature is a key parameter controlling solubility or precipitation of metals in hydrothermal fluids (Reed, 1983). The presence of Fe-Ca-silicates associated with the mineralization at the deepest structural position of the MC'IS indicates temperature of about $425 \pm 75^{\circ} \mathrm{C}$ (Gustafson, 1974; Coltat et al., 2019b). Th val ishing of Fe-Ca-silicates at Snake Pit may thus likely reflect a decrease of the tempe atu e upwards. Also, at Snake Pit, the mineralization is mainly comprised of pyrite against $w_{j}$ rrhotite, a feature consistent with a potential slight temperature decrease and changes of $\iota \lambda_{n}$, and $f_{\mathrm{S} 2}$ (Hannington et al., 1995).

$\mathrm{Ni}$ is rather immobile in low-T fluids $\left(<400^{\circ}{ }^{\circ}\right.$, whereas Co is mobile in fluids at lower temperatures, what is inferred by the presenc of co-rich minerals in both low-T and high-T chimneys at present-day systems (Fouc 'et et al., 2010). This may explain the lack of $\mathrm{Ni}$ enrichment or depletion of the mine: alized rocks upwards and the slight decrease of Co at Snake Pit (figure 5), leaving an apr $\mathrm{Ar} / \mathrm{t}$ decrease of the $\mathrm{Co} / \mathrm{Ni}$ ratio at Snake Pit (figure 6). The present-day systems extend tie variations, being rather poor in $\mathrm{Ni}$ (few nickel has been transported towards the seaflo ${ }^{-}$) and rather rich in Co (figure 5). The decrease of the Co/Ni ratio observed upwards (fi cure 5) could be thus, at least partly the sign of a temperature decrease.

Selenium solubility has been poorly investigated, using thermodynamic modelling, at temperatures higher than $300^{\circ} \mathrm{C}$ (Huston et al., 1995; Xiong et al., 2003) which may likely be considered in the root zone of hydrothermal systems. Most of metals have solubility which decreases with temperature (Reed and Palandri, 2006), thus one may expect that the same effect would prevail for Se. Also, it may be envisaged that a temperature decrease of the hydrothermal fluid would have only lowered the solubility of Se complexes and precipitated Se in sulfides.

$p H$. Drastic $\mathrm{pH}$ changes are expected to occur during the uprising of hydrothermal fluid and mixing with seawater (Reed and Palandri, 2006). Generally, HT hydrothermal fluids in ultramafic settings are highly acidic (Charlou et al., 2002; Tivey, 2007) whereas seawater is 
slightly basic $\mathrm{pH}$ (7.8). The mixing between these two fluids causes abrupt $\mathrm{pH}$ changes, destabilizing the metal complexes carried in the hydrothermal fluids and ending with metal deposition. Se is more efficiently mobilizable under acidic conditions (Huston et al., 1995) explaining its presence in typical hydrothermal fluids. Hence, a rapid increase of the $\mathrm{pH}$ would lead to Se precipitation from the hydrothermal fluid, a scenario supported by the highest Se content measured in metal-bearing phases from the upper part of the system, which is consistent with a progressive mixing between the hydrothermal fluid and seawater.

$f_{\mathrm{O} 2}, f_{\mathrm{S} 2}$. The oxygen and sulfur fugacity are highly modified in hydrothermal systems during the mixing of the hydrothermal fluid with seawater. Tho pyrite-pyrrhotite-magnetite assemblage represent a buffer both for $f_{\mathrm{O} 2}$ and $f_{\mathrm{S} 2}$ (Hanningt $\mathrm{n}$ el al., 1995). The presence of magnetite and pyrrhotite at apparent textural equilibr um at Cotschen and Marmorera indicates medium $f_{\mathrm{O} 2}$ and low $f_{\mathrm{S} 2}$. At Snake Pit, the anva -ition of pyrite, as the main metalbearing phase, and the absence of magnetite both su $_{\zeta_{c}}$ rer $_{i}$ an increase of the $f_{\mathrm{S} 2}$ and possibly $f_{\mathrm{O} 2}$ at very high $f_{\mathrm{S} 2}$ (Hannington et al., 1995).

Selenium is more efficiently carried by oxidis $\mathrm{d}$ tıulds rather reduced ones and is more easily transported under medium $\left(\sim 150^{\circ} \mathrm{C}\right) \mathrm{r}$, the . than hot $\left(\sim 300^{\circ} \mathrm{C}\right)$ conditions (Huston et al., 1995). At HT $\left(300^{\circ} \mathrm{C}\right)$, in the stability field of pyrite (agreeing with the mineralogy reported at Snake pit), Se is transported under i s s suced form $\mathrm{H}_{2} \mathrm{Se}$ (Xiong et al., 2003). This indicates that while an overall oxidation of $t_{1}{ }^{\prime}$ system would occurred, it remained reduced enough to prevent modification of the $\mathrm{Se}$ necration in the hydrothermal fluid. Also, Se is expected to be more enriched in fluid und $\bullet r$ th, conditions where pyrite is stable. Hence, one would expect that oxidation of the hyc roth rmal fluid would enhance Se leaching from the basement rocks but would keep Se into $t_{1}$ : hydrothermal fluid. This should have decreased the Se content in sulfides formed at Snake pit, a reverse trend than the one reported. An oxidation of the hydrothermal fluid upwards, therefore does not entirely satisfy the apparent increase of the Se content in sulfides.

\subsection{Model of circulation: mixing with seawater during upwards hydrothermal circulation}

The increase of the Se content in chalcopyrite and pyrrhotite and the decrease of the Co/Ni ratio upwards indicate variations of the temperature, $\mathrm{pH}, f_{\mathrm{O} 2}$ and $f_{\mathrm{S} 2}$ in the hydrothermal system. A simple model of progressive decrease of the temperature and/or increase of the $f_{\mathrm{O} 2}$ of the hydrothermal fluid does not allow to reconcile neither the evolution of these 
geochemical markers nor the observed mineralogical assemblages. So, we propose a model of fluid mixing to explain the geochemical and mineralogical variations observed at the MCHS (figure 14). In this model, HT hydrothermal fluids mixed with seawater as it flew upwards. The seawater percolated in the host serpentinites, and likely moved towards the main hydrothermal channel flow as a result of small-scale circulation paths.

The $\mathrm{Co} / \mathrm{Ni}$ ratio of the mineralized rocks is between those of barren serpentinites $(0.05)$ and seawater (0.0025). The seawater activity is maximal at Snake Pit where the lowest $\mathrm{Co} / \mathrm{Ni}$ ratios are reported, what is intuitive as Snake Pit is closer to the detachment than Cotschen. The progressive mixing between the HT hydrothermal fluid and seawater is likely responsible for the decrease of the temperature and the increase of the $f_{\mathrm{O} 2}$.

A seawater-derived fluid was more oxidized than the uprisin this fluid may represent an additional source for Se. The $\mathrm{n}$ ixin z̧ between these two fluids was likely efficient to destabilize $\mathrm{H}_{2} \mathrm{Se}$ complexes during suifide formation and to enrich $\mathrm{Se}$ in sulfides. This leaves the Se increase in the mineraliz tir $n$ upwards (figure 5). However, we cannot preclude that part of the Se enrichmer. ' pwards was only due to the temperature decrease of the hydrothermal fluid. A comk nation of the two processes (i.e. temperature decrease and mixing with seawater) is th. "roposed to explain the increase of the Se content in sulfides upwards.

The high contents of Mn and Mo (t: os _ 3) of chalcopyrite at Snake Pit agree with a lowering of the temperature partly due $\mathrm{t} \Omega$ ' $\mathrm{h}$ mixing with seawater. In present-day hydrothermal systems, $\mathrm{Mn}$ is found in oxy. 'droxides formed at the outer part of hydrothermal systems (Fouquet et al., 2010) whe te perature is low $\left(<30^{\circ} \mathrm{C}\right)$ and oxidation conditions favor its precipitation. The increa e or the $\mathrm{MnO}$ content in rocks at Snake Pit is thus consistent with an overall oxidation of the ystem during the mixing with seawater even if still low oxygen fugacity prevented the formation of Mn-rich phases.

Even if a hydrothermal model implying mixing between the hydrothermal fluid with seawater allows to explain the upwards variation of the geochemical markers, we cannot discard that a potential late refining occurred at Snake Pit. This refining could have been linked to the hydrothermal conditions that end up with carbonation. This hypothesis is consistent with the increase of the metal content together with the carbonation rate (figure 12) and could be the consequence of the $\mathrm{MnO}$ increase in mineralized rocks (figure 5) at Snake Pit. In that case, medium fluids $\left(\sim 130^{\circ} \mathrm{C}\right)$ would have remobilized a part of the former metal stock. The presence of chalcopyrite together with calcite filling cracks into pyrite grains and aggregates 
at Snake Pit likely indicates that a slight part of the $\mathrm{Cu}$ stock has been remobilized during carbonation. However, it does not explain the high contents of $\mathrm{Zn}, \mathrm{Co}$ and Ni notably because that we have no textural evidence for late enrichment of these elements. Another hypothesis is then that the most carbonated sample at Snake Pit was fortuitously the most mineralized during the former hydrothermal stage. Only an extensive sampling set could allow specifying this point.

In the figure 13, the exact pathway of fluids is speculative. The fluids may have used the detachment plane itself as a channel or percolate through fractures in the serpentinite basement. HT fluids might have derived from several sources $\boldsymbol{~}^{\mathbf{r}}$ a combination of sources. These are i) modified seawater (i.e. reduced and acidic) wl ich vould have interacted with mafic intrusions and serpentinites at depth, ii) serpentinizi tion reactions and iii) exsolution of magmatic fluids. These fluids get heated in-depth thinks to the cooling of magmatic intrusions where they leach metals from the baseme.t ocks, presumably serpentinites and mafic rocks, similarly to what is proposed in pre e t-day ultramafic-hosted systems (Marques et al., 2006). Also, it may be envisaged that seawater itself could has contributed to metal enrichment especially for Se. Further $\mathrm{so}^{+}$spic analyses ( $\mathrm{Sr}$ isotope signatures of $\mathrm{Fe}-\mathrm{Ca}-$

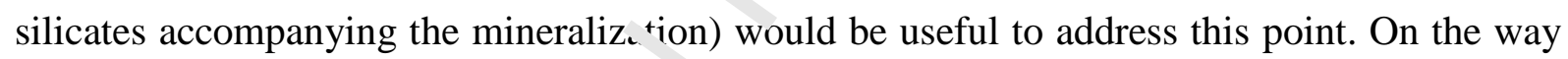
back to the surface, the HT hydroth sr... al fluid is focalized along preferential pathways (like the contact between the dyke ar $\mathrm{d}$ he serpentinites at Marmorera) and progressively mixes upwards with seawater (with : lower temperature) that impregnated the host serpentinites. Where the F/R ratio increa red i.e. in area where the fluid flow was maximum), the $\mathrm{Co} / \mathrm{Ni}$ ratio of the mineralizition increased (figure 13B). This hydro-metallogenic model is consistent with the lates seawater-derived carbonation of mantle rocks (Coltat et al., 2019b). It also reconciles the mineralogical evolution observed at Snake Pit by an overall oxidation during the mineralizing event thanks to the influx of serpentinite-hosted seawater. 


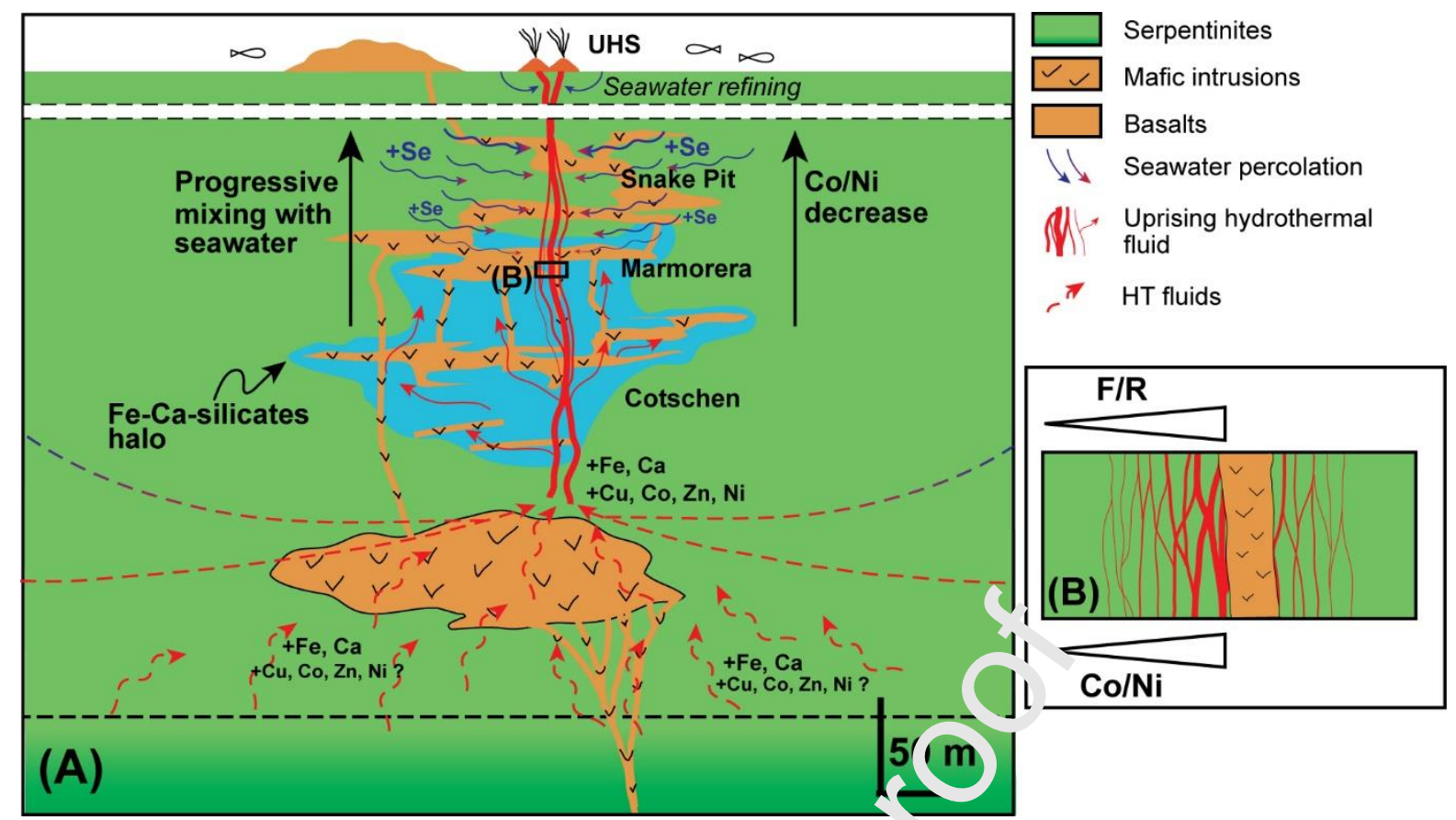

Figure 13. Hydrodynamic and metallogenic model fo $\cdot$ the formation of the mineralized system at the MCHS (the carbonation event occurred sibse.rently and is not displayed). The mineralization forms from the progressive mix $\vee \mathrm{g}$,etween the HT hydrothermal fluid and seawater upwards. The exact source for $r$ en 's r. mains unknown. See text for details.

\subsection{Insights for present-day black smし'er deposits}

The $\mathrm{Co} / \mathrm{Ni}$ ratio of present-day mir er llization at the seafloor is higher than the one of serpentinite (figure 3, 6). Alon', we MCHS vertical section, we have documented a decrease of this ratio at Snake Pit in res nonse to a decrease of the temperature, conditions favorable for cobalt mobility and nicke' nrusipitation. On the other hand, the fluid that interacted with the rocks should display a ig: $\mathrm{Co}_{\mathrm{N}} \mathrm{Ni}$ ratio. When these fluids reach the seafloor, they undergo an abrupt chemical discha: itself. The high $\mathrm{Co} / \mathrm{Ni}$ of present-day systems thus likely represents the final product of the chromatographic evolution recorded along the MCHS section. Although we have no petrographic evidence (e.g. coeval precipitation of $\mathrm{Ni}$ and Co-rich sulfides with calcite), another process to explain the high $\mathrm{Co} / \mathrm{Ni}$ ratio could relate to the remobilization of the $\mathrm{Co}$ stock during late carbonation without strong incidence on $\mathrm{Ni}$. This would enrich the mineralization in Co relative to $\mathrm{Ni}$ and increase the $\mathrm{Co} / \mathrm{Ni}$ ratio at Snake Pit.

The progressive increase of the Se content upwards recorded both in chalcopyrite and pyrrhotite is clear (figure 5). It is likely indicative that Se was more efficiently precipitated from the hydrothermal fluid in the upper parts of the section. Also, a part of Se would have 
been brought by seawater. In present-day systems, Se is enriched in HT chimneys (rich in $\mathrm{Cu}$ ) whereas LT chimneys (rich in Fe and Zn) are more depleted (Rouxel et al., 2004b). However, the $\mathrm{Cu}$ content of present-day SMS and $\mathrm{Cu}$-rich MS at the MCHS is comparable but chalcopyrite in the latter is depleted in Se compared to present-day equivalents. This indicates that process other than only temperature-related would enrich the mineralization formed at the seafloor. Martin et al. (2018), based on geochemical signatures of the mineralization at Troodos, showed that Se enrichment from sulfide dissolution occurred during oxidation processes. It might be expected that similar processes occur at present-day SMS likely during the circulation of seawater-derived oxidized fluids interacting with the former mineralization. The high Se content of chalcopyrite measured in present-day ri.neralized systems (figure 5) could thus be the final stage of the evolution recorded alon? th MCHS section coupled to potential late refining processes and possible volatile mą mat 2 additions (Keith et al., 2016; Melekestseva et al., 2017; Patten et al., 2020).

Zinc has unusually low concentration in the min 10 ization at the MCHS compared to presentday black smokers. It is unlikely due to diffe ent intensities of hydrothermal alteration since $\mathrm{Cu}, \mathrm{Fe}$ and $\mathrm{Co}$ contents in $\mathrm{Cu}$-rich MS ar comparable to those of UHS and MHS. In the latter, $\mathrm{Zn}$ is enriched in low-T chimrivs (Fouquet et al., 2010) suggesting that it is soluble at low temperatures in hydrothermal $\mathrm{f}^{\prime} \mathrm{dl}^{-}$- (Reed and Palandri, 2006). Therefore, the depletion of $\mathrm{Zn}$ at the MCHS may be due t'ie '-ign temperature of hydrothermal fluids in which $\mathrm{Zn}$ was still soluble and did not pi cipıate to form $\mathrm{Zn}$ sulfides. Nevertheless, the low $\mathrm{Zn}$ concentrations measured in the wineralization at the MCHS could also be the consequence of a low budget of mafic ock available to extract $\mathrm{Zn}$ (mafic rocks are enriched in $\mathrm{Zn}$ with respect with ultramafic ro ks, Fouquet et al., 2010).

Silver shares affinities with $\mathrm{Zn}$ in present-day mineralized systems where it is found in low-T sulfide chimneys (Fouquet et al., 2010). At the MCHS, the Cu-rich MS are slightly enriched in $\mathrm{Ag}$ (up to $119 \mathrm{ppm}$ ) compared to present-day mineralized systems. But the low $\mathrm{Ag}$ content at the MCHS with respect to UHS indicates that, similarly to $\mathrm{Zn}, \mathrm{Ag}$ was not efficiently precipitated and was evacuated in the hydrothermal fluid towards the surface. Noteworthy is that in chalcopyrite at Marmorera (figure 9), the content of $\mathrm{Ag}$ increases in the most mineralized sample. This suggests that even in high-T mineralogical assemblages, Ag can be scavenged where the intensity of hydrothermal alteration increases.

Similarly, Ge shows geochemical affinities with Zn in UHS (Fouquet et al., 2010). Ge has been measured in pyrrhotite at the MCHS without apparent correlation to the intensity of 
hydrothermal alteration, whereas $\mathrm{Cu}$-rich MS are depleted in Ge. This may be explained by the solubility of Ge in hydrothermal fluids at the MCHS. As a consequence, it was likely transported together with Ag and $\mathrm{Zn}$ towards the surface.

Gold is an element locally enriched at ultramafic-hosted systems (Fouquet et al., 2010; Melekestseva et al., 2017; Webber et al., 2017; Knight et al., 2018). There, native or electrum gold co-precipitates with sulfides from the hydrothermal fluid in sulfides chimneys. At the MCHS, the mineralization is nearly Au-free; only a low Au content is reported in one sample of the $\mathrm{Cu}$-rich MS facies (table 1). The lack of gold enrichment may be explained by two reasons: i) it was not extracted from the country rocks, ii, it was not trapped in the mineralization and was transported in hydrothermal fluids his her $\mathrm{n}$ the system. At the MCHS we do not know if the barren serpentinites are depleted in Au. However, at first order, there is no direct reason to preclude that $\mathrm{Au}$ was retained in the $\iota^{\text {? }}$ sement rocks during hydrothermal alteration at the MCHS. Its absence, hence, rather suyc rer is that it was not incorporated in the mineralization. Au is mainly transported as chlc 10.2 complexes in high-T acidic and oxidized hydrothermal fluids (Fouquet et al., 2010). Tl : lack of Au in the mineralization suggests that the mixing between the hydrothermal flu $\gamma \mathrm{r}$, ith minute proportions of seawater as it proposed for the MCHS (figure 13) was not ef: : cient to destabilize the complexes and precipitate gold. A much more efficient trap is the ar : val of the hydrothermal fluid at the seafloor, where seawater overwhelmingly dominc as the mixing.

Finally, present-day sea` oor massive sulfides may content significant tellurium contents (Fouquet et al., 2010; Wohlgemuth-Ueberwasser et al., 2015). The position of Te in the element periodic table indicates that it shares similar geochemical behaviors with $\mathrm{Se}$ in hydrothermal fluids and is thought to be enriched in sulfides (Hertogen et al., 1980). This would explain why both Te and Se are found in present-day ultramafic-hosted systems. There, Te is sequestered in pyrite, whereas Se has more affinities with chalcopyrite (Rouxel et al., 2004b; Martin et al., 2020). At the MCHS, the Te content of the mineralization is lower than the one reported at UHS and Te does not show positive correlation to Se. We might thus suggest that Te is scavenged in pyrite at Snake Pit. The different Te content reported in chalcopyrite between the MCHS and UHS could be explained by processes similar to those controlling the Se enrichment at present-day settings. 


\section{Conclusion}

The geochemical study of the Marmorera-Cotschen hydrothermal system brings insights on the element distribution occurring below present-day ultramafic-hosted mineralized systems. For the first time we report chemical signatures of metal-bearing phases and whole rocks equivalent to the root zone of present-day ultramafic-hosted hydrothermal systems. As a consequence, this study enhances to better understand element partitioning during metal deposition at depth. Hence, it allows to constrain hydrothermal processes which occur beneath active black smoker systems and are responsible for seafloor massive sulfides formation at the seafloor. The main conclusions of this study are as follows:

(1) The upwards circulation of the mineralizing fluid wa acr ompanied by a temperature decrease. This may have provoked a fractionation $c^{f}$ th $f \mathrm{Co} / \mathrm{Ni}$ ratio.

(2) The upwards mixing with seawater coming $f \ldots m$ the surrounding serpentinites was responsible for the increase of the $f_{\mathrm{O} 2}$ and $\mathrm{Se} \mathrm{co}_{\mathrm{e}} \cdot \mathrm{nt}$ upwards.

(3) The $\mathrm{Co} / \mathrm{Ni}$ ratio evolves laterally as a poxy of the intensity of the fluid/rock interactions.

(4) The temperature decrease upwaru . alay as well be linked to the mixing with seawater coming from the serpentinites.

(5) Late carbonation affecting th: ystem was possibly responsible for minor metal remobilization. In presen-daj setting, it could be the cause of secondary low-grade deposits.

The Marmorera-Cotschen 1. vdr thermal system should be considered further as a natural laboratory on which app vin, other tools, like isotope geochemistry, to better understand the processes acting at depth, elow black-smokers type hydrothermalism.

\section{Acknowledgments}

The authors would like to thank S. McClenaghan in the Trinity College in Dublin for the help during the acquisition of LA-ICPMS data. A. Boissier and S. Cheron are thanked for the acquisition and processing of WD-XRF data. J. Langlade is acknowledged for the acquisition of EPMA analyses. This study was founded through CNRS-INSU-CESSUR and University of Rennes 1 "Défis Scientifiques” grants (accorded to P. Boulvais and R. Coltat). 


\section{References}

Amann, M., Ulrich, M., Manatschal, G., Pelt, E., Epin, M.E., Autin, J., Sauter, D., 2020. Geochemical characteristics of basalts related to incipient oceanization: The example from the Alpine-Tethys OCTs. Terra Nov. 32, 75-88. https://doi.org/10.1111/ter.12438

Andreani, M., Escartin, J., Delacour, A., Ildefonse, B., Godard, M., Dyment, J., Fallick, A.E., Fouquet, Y., 2014. Tectonic structure, lithology, and hydrothermal signature of the Rainbow massif (Mid-Atlantic Ridge 36²' ${ }^{\prime}$ ). Geochemistry, Geophys. Geosystems 15, 3543-3571. https://doi.org/10.1002/2014GC005269.Received

Beaulieu, S.E., Baker, E.T., German, C.R., Maffei, A., 2013. An authoritative global database for active submarine hydrothermal vent fields. Geochen. ‘try, Geophys. Geosystems 14, 4892-4905. https://doi.org/10.1002/2013GC004998

Candela, P.A., Wylie, A.G., Burke, T.M., 1989. Gr nesis of the ultramafic rockassociated Fe-Cu-Co-Zn-Ni deposits of the Sykesvi11. Listrict, Maryland Piedmont. Econ. Geol. 84, 663-675. https://doi.org/10.2113/gsecongen.c ‘.3.663

Charlou, J.L., Donval, J.P., Fouquet ( , Jean-baptiste, P., Holm, N., 2002. Geochemistry of high $\mathrm{H} 2$ and $\mathrm{CH} 4$ vent flric issuing from ultramafic rocks at the Rainbow hydrothermal field (36²' N, MAR). Chu. ' Geol. 191, 345-359.

Coltat, R., Boulvais, P., Branч'et, Y., Collot, J., Epin, M.E., Manatschal, G., 2019. Syntectonic carbonation during s: $\mathrm{n} k$ omatic mantle exhumation at an ocean-continent transition. Geology 47, 183-186 nttp://doi.org/10.1130/G45530.1

Coltat, R., Branquet, Y., Gautier, P., Campos Rodriguez, H., Poujol, M., Pelleter, E., McClenaghan, S., Manats hal G., Boulvais, P., 2019. Unravelling the root zone of ultramafic-hosted bla`k : mol ers-like hydrothermalism from an Alpine analog. Terra Nov. 31, 549-561. https://doi.org/1 ).1111/ter.12427

Coltat, R., Branquet, Y., Gautier, P., Boulvais, P., Manatschal, G., in rev. The nature of the interface between basalts and serpentinized mantle in oceanic domains: insights from a geological section in the Alps. Tectonophysics.

Dare, S.A.S., Barnes, S.-J., Beaudoin, G., Méric, J., Boutroy, E., Potvin-Doucet, C., 2014. Trace elements in magnetite as petrogenetic indicators. Miner. Depos. 49, 785-796. https://doi.org/10.1007/s00126-014-0529-0

De la Roche, H., Marchal, M., 1978. Leucogranites et granites du massif de Valencia de Alcantara (Espagne): Relations entre compositions minéralogiques et faciès mineral. Sci. la Terre 22, 181-200. 
Desmurs, L., Müntener, O., Manatschal, G., 2002. Onset of magmatic accretion within a magma-poor rifted margin: a case study from the Platta ocean-continent transition, eastern Switzerland. Contrib. to Mineral. Petrol. 144, 365-382. https://doi.org/10.1007/s00410-0020403-4

Dietrich, V., 1972. Die sulfidischen Vererzungen in den Oberhalbsteiner Serpentiniten. Geotech. Ser. 49, 129.

Dietrich, V., 1970. Die Stratigraphie der Platta-Decke: facielle Zusammenhänge zwischen Oberpenninikum und Unterostalpin. Eclogae Geol. Helv. 63, 631-671.

Dunoyer de Segonzac, G., Bernoulli, D., 1976. Diagenese et metamorphisme des argiles dans le Rhetien Sud-alpin et Austro-alpin (Lombardie . Grisons). Bull. la Société Géologique Fr. S7-XVIII, 1283-1293. https://doi.org/10.2112'gss fbull.S7-XVIII.5.1283

Epin, M., Manatschal, G., Amannn, M., 2017. Det nin ; diagnostic criteria to describe the role of rift inheritance in collisional orogens lis case of the Err-Platta nappes (Switzerland). Swiss J. Geosci. 110, 419-438. https:/凡 ’i Jrg/10.1007/s00015-017-0271-6

Epin, M.E., Manatschal, G., Amman ri., Ribes, C., Clausse, A., Guffon, T., Lescanne, M., 2019. Polyphase tectono-magr atic evolution during mantle exhumation in an ultra-distal, magma-poor rift domain: $\mathrm{e}_{\mathrm{s}} \mathrm{Pm}_{\mathrm{L}}$ le of the fossil Platta ophiolite, SE Switzerland. Int. J. Earth Sci. 108, 2443-2467. http *//doi.org/10.1007/s00531-019-01772-0

Etoubleau, J., Cambon, P., 'o rret, Y., Henry, K., Moal, S., 1996. Séparation des métaux nobles (Pt, $\mathrm{Au}$ ) d'une mati ^e géologique par chromatographie d'échange d'ions et détermination par spectromé rie de fluorescence X. Le J. Phys. IV 06, 843-852. https://doi.org/10.1051/jp4:1996 $: 81$

Ferreiro Mähln ann R., 1995. Das Diagenese-Metamorphose-Muster von Vitrinitreflexion und Ilı.-" Kristallinität" in Mittelbünden und im Oberhalbstein, Teil 1: Bezüge zur Stockwerktektonik. Schweizerische Mineral. und Petrogr. Mitteilungen 75, 85122. https://doi.org/http://doi.org/10.5169/seals-57145 Nutzungsbedingungen

Foose, M.P., 1985. Setting of a Magmatic Sulfide Occurrence in a Dismembered Ophiolite, Southwestern Oregon, U.S. Geological Survey Bulletin 1626. Contributions to the Geology of Mineral Deposits.

Foose, M.P., Economou, M., Panayiotou, A., 1985. Compositional and mineralogic constraints on the genesis of ophiolite hosted nickel mineralization in the Pevkos Area, Limassol Forest, Cyprus. Miner. Depos. 20, 234-240.

Fouquet, Y., Cambon, P., Etoubleau, J., Charlou, J.L., Ondréas, H., Barriga, F.J.A.S., Cherkashov, G., Semkova, T., Poroshina, I., Bohn, M., Donval, J.P., Henry, K., Murphy, P., 
Rouxel, O., 2010. Geodiversity of Hydrothermal Processes Along the Mid-Atlantic Ridge and Ultramafic-Hosted Mineralization: A New Type of Oceanic $\mathrm{Cu}-\mathrm{Zn}-\mathrm{Co}-\mathrm{Au}$ Volcanogenic Massive Sulfide Deposit. Geophys. Monogr. Ser. 188, 321-367.

Froitzheim, N., Manatschal, G., 1996. Kinematics of Jurassic rifting, mantle exhumation, and passive-margin formation in the Austroalpine and Penninic nappes (eastern Switzerland). Geol. Soc. Am. Bull. 108, 1120-1133.

Froitzheim, N., Schmid, S.M., Conti, P., 1994. Repeated change from crustal shortening to orogen-parallel extension in the Austroalpine units of Graubünden Graubünden. Eclogae Geol. Helv. 87, 559-612.

Grant, H.L.J., Hannington, M.D., Petersen, S., Frisc.` ${ }^{\circ}$ M., Fuchs, S.H., 2018. Constraints on the behavior of trace elements in the activ ly-t rming TAG deposit, MidAtlantic Ridge, based on LA-ICP-MS analyses of 1 vrit. Chem. Geol. 498, 45-71. https://doi.org/https://doi.org/10.1016/j.chemgeo.2018 n§. $? 19$

Gustafson, W.I., 1974. The Stability of Andrac:te Hedenbergite, and Related Minerals in the System Ca-Fe-Si-O-H. J. Petrol. 15, 455- ${ }^{\circ}$.

Hannington, M.D., Jonasson, I.R.. Frrzly, P.M., Petersen, S., 1995. Physical and Chemical Processes of Seafloor Mineral rat on at Mid-Ocean Ridges. Geophys. Monogr. Ser. $91,115-157$.

Hertogen, J., Janssens, M.-J, J.Inie, H., 1980. Trace elements in ocean ridge basalt glasses: implications for fraction atı ns during mantle evolution and petrogenesis. Geochim. Cosmochim. Acta 44, 2125-2143. https://doi.org/https://doi.org/10.1016/00167037(80)90209-4

Huston, D.L., Siє S.r '., Suter, G.F., 1995. Selenium and its importance to the study of ore genesis: the theores al basis and its application to volcanic-hosted massive sulfide deposits using pixeprobe analysis. Nucl. Inst. Methods Phys. Res. B 104, 476-480. https://doi.org/10.1016/0168-583X(95)00462-9

Keith, M., Haase, K.M., Klemd, R., Krumm, S., Strauss, H., 2016. Systematic variations of trace element and sulfur isotope compositions in pyrite with stratigraphic depth in the Skouriotissa volcanic-hosted massive sulfide deposit, Troodos ophiolite, Cyprus. Chem. Geol. 423, 7-18. https://doi.org/10.1016/j.chemgeo.2015.12.012

Knight, R.D., Roberts, S., Webber, A.P., 2018. The influence of spreading rate, basement composition, fluid chemistry and chimney morphology on the formation of goldrich SMS deposits at slow and ultraslow mid-ocean ridges. Miner. Depos. 53, 143-152. https://doi.org/10.1007/s00126-017-0762-4 
Large, R.R., 1977. Chemical evolution and zonation of massive sulfide deposits in volcanic terrains. Econ. Geol. 72, 549-572. https://doi.org/10.2113/gsecongeo.72.4.549

Leblanc, M., Billaud, P., 1982. Cobalt arsenide orebodies related to an upper Proterozoic ophiolite: Bou Azzer (Morocco). Econ. Geol. 77, 162-175. https://doi.org/10.2113/gsecongeo.77.1.162

Marques, A.F.A., Barriga, F.J.A.S., Chavagnac, V., Fouquet, Y., 2006. Mineralogy, geochemistry, and $\mathrm{Nd}$ isotope composition of the Rainbow hydrothermal field, Mid-Atlantic Ridge. Miner. Depos. 41, 52-67. https://doi.org/10.1007/s00126-005-0040-8

Marques, A.F.A., Barriga, F.J.A.S., Scott, S.D., 2007. Sulfide mineralization in an ultramafic-rock hosted seafloor hydrothermal system: From $\operatorname{ser}_{\mathbf{p}}$-ntinization to the formation of $\mathrm{Cu}-\mathrm{Zn}-(\mathrm{Co})$-rich massive sulfides. M r. Geol. 245, 20-39. https://doi.org/10.1016/j.margeo.2007.05.007

Martin, A.J., Keith, M., Parvaz, D.B., McDrna'd, I., Boyce, A.J., McFall, K.A., Jenkin, G.R.T., Strauss, H., MacLeod, C.J., 2020. Eftu ${ }^{-t s}$ of magmatic volatile influx in mafic VMS hydrothermal systems: Evidence from the 11 ondos ophiolite, Cyprus. Chem. Geol. 531, 119325. https://doi.org/https://doi.org/10.101C i.chemgeo.2019.119325

Martin, A.J., McDonald, I., MacL `or', C.J., Prichard, H.M., McFall, K., 2018. Extreme enrichment of selenium in the Aplik: Cyprus-type VMS deposit, Troodos, Cyprus. Mineral. Mag. 82, 697-724. https://doi.org/1C.1. ९//mgm.2018.81

Maslennikov, V. V, Nasinnikova, S.P., Large, R.R., Danyushevsky, L. V, Herrington, R.J., Ayupova, N.?., Laykov, V.V., Lein, A.Y., Melekestseva, I.Y., Tessalina, S.G., 2017. Chimneys in Pale zoic massive sulfide mounds of the Urals VMS deposits: Mineral and trace eleme $\mathrm{t}$ co nparison with modern black, grey, white and clear smokers. Ore Geol. Rev. 85, 64-106. hı ps://doi.org/10.1016/j.oregeorev.2016.09.012

McCaig, A.M., Cliff, R.A., Escartín, J., Fallick, A.E., MacLeod, C.J., 2007. Oceanic detachment faults focus very large volumes of black smoker fluids. Geology 35, 935-938. https://doi.org/10.1130/G23657A.1

Melekestseva, I.Y., Maslennikov, V. V, Tret'yakov, G.A., Nimis, P., Beltenev, V.E., Rozhdestvenskaya, I.I., Maslennikova, S.P., Belogub, E. V, Danyushevsky, L., Large, R., Yuminov, A.M., Sadykov, S.A., 2017. Gold- and Silver-Rich Massive Sulfides from the Semenov-2 Hydrothermal Field, $13^{\circ} 31.13^{\prime}$ N, Mid-Atlantic Ridge: A Case of Magmatic Contribution? Econ. Geol. 112, 741-773.

Müntener, O., Manatschal, G., Desmurs, L., Pettke, T., 2010. Plagioclase Peridotites in Ocean-Continent Transitions: Refertilized Mantle Domains Generated by Melt Stagnation in 
the Shallow Mantle Lithosphere. J. Petrol. 51, 255-294. https://doi.org/10.1093/petrology/egp087

Nadoll, P., Angerer, T., Mauk, J.L., French, D., Walshe, J., 2014. The chemistry of hydrothermal magnetite: A review. Ore Geol. Rev. 61, 1-32. https://doi.org/10.1016/j.oregeorev.2013.12.013

Nimis, P., Zaykov, V. V, Omenetto, P., Melekestseva, I.Y., Tessalina, S.G., Orgeval, J.-J., 2008. Peculiarities of some mafic - ultramafic- and ultramafic-hosted massive sulfide deposits from the Main Uralian Fault Zone, southern Urals. Ore Geol. Rev. 33, 49-69. https://doi.org/10.1016/j.oregeorev.2006.05.010

Onuk, P., Melcher, F., Mertz-Kraus, R., Gäbler, ¿i.-E., Goldmann, S., 2017. Development of a Matrix-Matched Sphalerite Referenc N Naterial (MUL-ZnS-1) for Calibration of In Situ Trace Element Measurements by I ase Ablation-Inductively Coupled Plasma-Mass Spectrometry. Geostand. Geoana.ytical Res. 41, 263-272. https://doi.org/10.1111/ggr.12154

Paton, C., Hellstrom, J., Paul, B., Wood'.te d, J., Hergt, J., 2011. Iolite: Freeware for the visualisation and processing of mass spec. ometric data. J. Anal. At. Spectrom. 26, 25082518. https://doi.org/10.1039/C1JA1017.'B.

Patten, C.G.C., Pitcairn, I.K Alt, J.C., Zack, T., Lahaye, Y., Teagle, D.A.H., Markdahl, K., 2020. Metal fluxes ung magmatic degassing in the oceanic crust: sulfide mineralisation at ODP site 760? Izu-Bonin forearc. Miner. Depos. 55, 469-489. https://doi.org/10.1007/s00126 ר19-J0900-9

Patten, C.G.C., Pitc airn. I.K., Teagle, D.A.H., Harris, M., 2016. Sulphide mineral evolution and metal mol ility during alteration of the oceanic crust: Insights from ODP Hole 1256D. Geochim. Cosmo him. Acta 193, 132-159. https://doi.org/10.1016/j.gca.2016.08.009

Peltonen, P., Kontinen, A., Huhma, H., Kuronen, U., 2008. Outokumpu revisited: New mineral deposit model for the mantle peridotite-associated $\mathrm{Cu}-\mathrm{Co}-\mathrm{Zn}-\mathrm{Ni}-\mathrm{Ag}-\mathrm{Au}$ sulphide deposits. Ore Geol. Rev. 33, 559-617. https://doi.org/10.1016/j.oregeorev.2007.07.002

Perseil, E.A., Latouche, L., 1989. Découverte de microstructures de nodules polymétalliques dans les minéralisations manganésifères métamorphiques de Falotta et de Parsettens (Grisons-Suisse). Miner. Depos. 24, 111-116.

Pinto, V.H., Manatschal, G., Karpoff, A., Viana, A.R., 2015. Tracing mantle-reacted fluids in magma-poor rifted margins: The example of Alpine Tethyan rifted margins. Geochemistry, Geophys. Geosystems 16, 3271-3308. https://doi.org/10.1002/2015GC005830.Received 
Reed, M.H., 1983. Seawater-basalt reaction and the origin of greenstones and related ore deposits. Econ. Geol. 78, 466-485.

Reed, M.H., Palandri, J., 2006. Sulfide Mineral Precipitation from Hydrothermal Fluids. Rev. Mineral. Geochemistry 61, 609-631. https://doi.org/10.2138/rmg.2006.61.11

Rona, P.A., 1985. Black smokers on the Mid-Atlantic Ridge. Eos, Trans. Am. Geophys. Union 66, 682-683. https://doi.org/10.1029/EO066i040p00682-02

Rouxel, O., Fouquet, Y., Ludden, J.N., 2004a. Copper Isotope Systematics of the Lucky Strike, Rainbow, and Logatchev Sea-Floor Hydrothermal Fields on the Mid-Atlantic Ridge. Econ. Geol. 99, 585-600.

Rouxel, O., Fouquet, Y., Ludden, J.N., 2004b. Subsurfacu nrocesses at the lucky strike hydrothermal field, Mid-Atlantic ridge: Evidence from sulf ir, $s$ :lenium, and iron isotopes. Geochim. Cosmochim. Acta. https://doi.org/10.1016/j.gca. 200. .11.029

Schaltegger, U., Desmurs, L., Manatschal, G. N. ${ }^{*}$ ntener, O., Meier, M., Frank, M., Bernoulli, D., 2002. The transition from rifting to $s \epsilon_{i}$ f' jor spreading within a magma-poor rifted margin: field and isotopic constraints. Terr $₫$ sov. 14, 156-162.

Sohrin, Y., Iwamoto, S.I., Akiyama. S. Fuృıta, T., Kugii, T., Obata, H., Nakayama, E., Goda, S., Fujishima, Y., Hasegawa, H., Je ıa, K., Matsui, M., 1998. Determination of trace elements in seawater by fluorinated metal alkoxide glass-immobilized 8-hydroxyquinoline concentration and high-resolution i a tively coupled plasma mass spectrometry detection. Anal. Chim. Acta 363, 11-19. htt ss.,'Ivi.org/10.1016/S0003-2670(98)00074-9

Song, X.-Y., Zhou, M. F., Cao, Z.-M., Sun, M., Wang, Y.-L., 2003. Ni-Cu-(PGE) magmatic sulfide deposits in the Yangliuping area, Permian Emeishan igneous province, SW China. Miner. Depos. 38 83,-843. https://doi.org/10.1007/s00126-003-0362-3

Talhammer, O., ¿umpfl, E.F., Panayiotou, A., 1986. Postmagmatic, hydrothermal origin of sulfide and arsenide mineralizations at Limassol Forest, Cyprus. Miner. Depos. 21, 95-105.

Tao, C., Lin, J., Guo, S., Chen, Y.J., Wu, G., Han, X., Christopher, R., Yoerger, D.R., Zhou, N., Li, H., Su, X., Zhu, J., Legs, D.-, Tao, C., Lin, J., Guo, S., Chen, Y.J., Wu, G., Han, X., German, C.R., Yoerger, D.R., Zhou, N., Li, H., Su, X., Zhu, J., DY115-19 and DY115-20 Science Parties, 2012. First active hydrothermal vents on an ultraslow-spreading center: Southwest Indian Ridge. Geology 40, 47-50. https://doi.org/10.1130/G32389.1

Tivey, M.K., 2007. Generation of Seafloor Hydrothermal Vent Fluids and Associated Mineral Deposits. Oceanography 20, 50-65. 
Toffolo, L., Nimis, P., Martin, S., Tumiati, S., Bach, W., 2017. The Cogne magnetite deposit (Western Alps, Italy): A Late Jurassic seafloor ultramafic-hosted hydrothermal system? Ore Geol. Rev. 83, 103-126. https://doi.org/10.1016/j.oregeorev.2016.11.030

Webber, A.P., Roberts, S., Murton, B.J., Mills, R.A., Hodgkinson, M.R.S., 2017. The formation of gold-rich seafloor sulfide deposits: Evidence from the Beebe hydrothermal vent field, Cayman Trough. Geochemistry, Geophys. Geosystems 18, 2011-2027. https://doi.org/10.1002/2017GC006922.

Wilson, S.A., Ridley, W.I., Koenig, A.E., 2002. Development of sulfide calibration standards for the laser ablation inductively-coupled plasma mass spectrometry technique. J. Anal. At. Spectrom. 17, 406-409. https://doi.org/10.1039/B108, i ${ }^{7} \mathrm{H}$

Wohlgemuth-Ueberwasser, C.C., Viljoen, F., Pet rses, S., Vorster, C., 2015. Distribution and solubility limits of trace elements in hydr the mal black smoker sulfides: An in-situ LA-ICP-MS study. Georhu: Cosmochim. Acta. https://doi.org/10.1016/j.gca.2015.03.020

Xiong, Y., 2003. Predicted equilibrium c onstants for solid and aqueous selenium species to $300{ }^{\circ} \mathrm{C}$ : Applications to selenium $*$ ch inineral deposits. Ore Geol. Rev. 23, 259276. https://doi.org/10.1016/S0169-136\& , 73 J0038-6

Yuan, B., Yang, Y., Yu, I'. Zhao, Y., Ding, Q., Yang, J., Tang, X., 2018. Geochemistry of pyrite and chalcor yf ico irom an active black smoker in $49.6^{\circ} \mathrm{E}$ Southwest Indian Ridge. Mar. Geophys. Res. J? 441-461. https://doi.org/10.1007/s11001-017-9324-5

Zierenberg, R.A., Kosk: R.A., Morton, L., Bouse, R.M., Shanks, W.C., 1993. Genesis of massive sulfides depo its wa a sediment-covered sreading center, Escabana Trough, Southern Gorda Ridge. F con. Geol. 88, 2069-2098. 


\section{Declaration of interests}

$\bigotimes$ The authors declare that they have no known competing financial interests or personal relationships that could have appeared to influence the work reported in this paper.

$\square$ The authors declare the following financial interests/personal relationships which may be considered as potential competing interests: 